\title{
13. BIOSTRATIGRAPHY AND PALEOECOLOGY OF LATE CRETACEOUS ABYSSAL AGGLUTINATED FORAMINIFERS FROM THE WESTERN PACIFIC OCEAN (DEEP SEA DRILLING PROJECT HOLES 196A AND 198A AND OCEAN DRILLING PROGRAM HOLES 800A AND 801A) ${ }^{1}$
}

\author{
Winton G. Wightman ${ }^{2}$ and Wolfgang Kuhnt ${ }^{2}$
}

\begin{abstract}
Abyssal agglutinated foraminifers allow biostratigraphic correlation of Upper Cretaceous brown zeolitic claystones in Deep Sea Drilling Project Holes 196A and 198A and Ocean Drilling Program Holes 800A and 801A. Three agglutinated foraminiferal zones subdivide the strata overlying the Campanian to Cenomanian cherts. The lower zone is characterized by Hormosina gigantea, which is a Campanian zonal marker in the North Atlantic Ocean and western Tethys. A major correlation level, which was observed in all holes studied, is based on the acme of evolute Haplophragmoides spp. This acme zone was observed in Sample 129-801A-6R-CC, about $9 \mathrm{~m}$ above the first occurrence of $\mathrm{H}$. gigantea in Sample 129-801A-7R-1, 62-67 cm (approximately middle Campanian). The uppermost zone is characterized by dominant Paratrochamminoides spp. and in some instances common Bolivinopsis parvissimus (late Campanian to Maestrichtian). The available biostratigraphic data for the Upper Cretaceous of Sites 196, 198, 800, and 801 are correlated with the biochronologic framework of the North Atlantic, western Mediterranean, and Carpathians. Additionally, we use quantitative estimates of the diversity and abundance of agglutinated foraminiferal species to monitor general faunal trends with time in the western Pacific.
\end{abstract}

\section{INTRODUCTION}

Deep-water agglutinated foraminifers (DWAF) are often the only existing microfossils in Upper Cretaceous oceanic sediments deposited below the carbonate compensation depth (CCD). The biostratigraphic value of Late Cretaceous DWAF has often been neglected because the assemblage composition of this fossil group is extremely sensitive to environmental conditions. Different agglutinated assemblages and local ranges of DWAF may thus indicate changing environmental conditions rather than coeval biostratigraphic events. However, abyssal agglutinated foraminifers have been used successfully for biostratigraphic correlation of Upper Cretaceous successions on a local to basinwide scale. Krasheninnikov (1974) recognized two different assemblages of abyssal agglutinated foraminifers as useful in determining a stratigraphic succession in the Indian Ocean. Recent studies in the North Atlantic Ocean (Moullade et al., 1988; Kuhnt et al., 1989, Kuhnt and Moullade, 1991) and in the western Mediterranean realm (Kuhnt, 1990) have developed local biostratigraphic zonations of Late Cretaceous DWAF for these basins, which extended the zonation used in the Polish and Rumanian external Carpathians (Geroch and Nowak, 1984; Neagu, 1990; Kuhnt et al., in press).

The main objective of our study is to test the validity of using abyssal agglutinated foraminifers in interbasinal correlation. Material drilled at Ocean Drilling Program (ODP) Sites 800 and 801 supplements the incomplete data from Deep Sea Drilling Project (DSDP) Sites 196 and 198 (Krasheninnikov, 1973) in the eastern Pacific (Figs. 1 and 2). We give a taxonomic overview of 46 species of Late Cretaceous abyssal agglutinated foraminifers from the western $\mathrm{Pa}$ cific, which completes the initial report from DSDP Sites 196 and 198 (Krasheninnikov, 1973). The evolution of the faunal diversity and density of the Late Cretaceous DWAF shows characteristic trends within the North Atlantic Ocean basin and the western Tethys (Kuhnt and Moullade, 1991). One of the objectives of our study is to compare

'Larson, R. L., Lancelot, Y., et al., 1992. Proc. ODP, Sci. Results, 129: College Station, TX (Ocean Drilling Program).

${ }^{2}$ Centre for Marine Geology, Dalhousie University, Halifax, Nova Scotia B3H 3J5. Canada. the quantitative trends observed in the North Atlantic to those of the western Pacific. This may help us to explore the potential of DWAF for documenting late Mesozoic paleoceanographic changes.

\section{GEOLOGICAL SETTING}

Holes $800 \mathrm{~A}$ and $801 \mathrm{~A}$ are located in the abyssal Pigafetta Basin in the far western part of the Pacific plate, between Japan and Australia and to the east of the Mariana Islands. They were drilled at $21^{\circ} 55.38^{\prime} \mathrm{N}$, $152^{\circ} 19.3^{\prime} \mathrm{E}$, and $18^{\circ} 38.568^{\prime} \mathrm{N}, 156^{\circ} 21.57^{\prime} \mathrm{E}$, in 5686 and $5673 \mathrm{~m}$ water depth, respectively. The Pigafetta Basin is surrounded by several groups of islands, atolls, and guyots (Fig. 1) and is about $5680 \mathrm{~m}$ deep. Magnetic anomaly lineation mapping indicates that this part of the Pacific plate is underlain by the oldest known ocean crust, of Middle to Early Jurassic age. Accordingly, these sites had already undergone much subsidence during the Late Cretaceous, and Late Cretaceous water depths may have already exceeded $5000 \mathrm{~m}$.

Sites 800 and 801 are characterized by the absence of a substantial accumulation of Cretaceous volcanogenic sediments and a low total sediment thickness over basement on the order of $450-550 \mathrm{~m}$. Sedimentation rates for Upper Cretaceous sediments were about 5.1 $\mathrm{m} / \mathrm{m}$.y. at Site 800 and about $2.4 \mathrm{~m} / \mathrm{m}$.y. at Site 801 .

Hole 196A was drilled on the abyssal floor east of the Izu-Bonin Trench $\left(30^{\circ} 07.0^{\prime} \mathrm{N}, 148^{\circ} 34.5^{\prime} \mathrm{E}\right)$ in $6184 \mathrm{~m}$ water depth. Basement was not reached at Site 196, but judging from seismic reflection profiles, it is a few hundred meters below the total penetration of $623 \mathrm{~m}$ below seafloor (mbsf) and must be of Jurassic age (Heezen, MacGregor, et al., 1973). Hole 198A was drilled on the abyssal plain north of Marcus Island at $25^{\circ} 49.5^{\prime} \mathrm{N}, 154^{\circ} 35.0^{\prime} \mathrm{E}$, in a water depth of $5848 \mathrm{~m}$. Mechani$\mathrm{cal}$ failure of the rig prevented the penetration of basement, which has been estimated to be Early Cretaceous or older (Heezen, MacGregor, et al., 1973).

\section{MATERIALS AND METHODS}

Two samples of 20 and $30 \mathrm{~cm}^{3}$, respectively, were removed from each core section $(1.5 \mathrm{~m})$ at approximately equal intervals and supplemented by shipboard samples of 10 and $40 \mathrm{~cm}^{3}$ (core-catcher samples) from Holes $800 \mathrm{~A}$ and $801 \mathrm{~A}$. The sediment samples were 


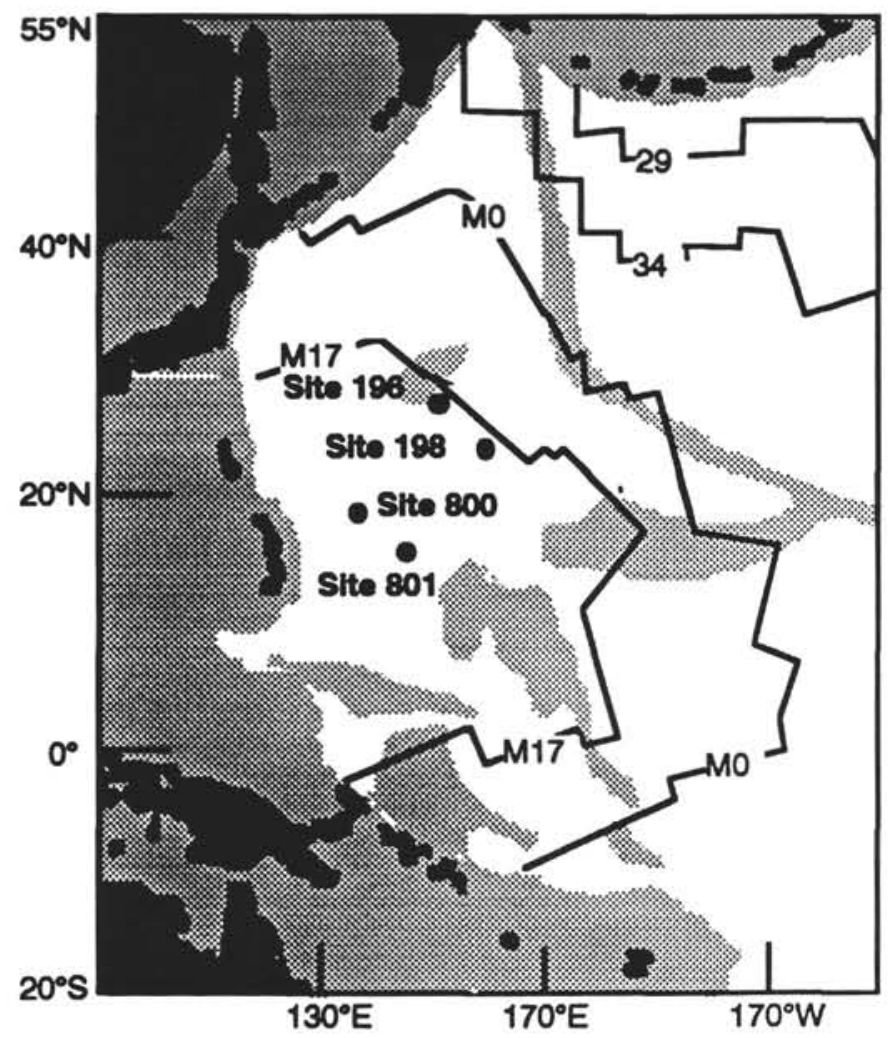

Figure 1. Location of DSDP Sites 196 and 198A and ODP Sites 800 and 801 (modified from Shipboard Scientific Party, 1990a, 1990b). Jagged contours represent magnetic lineations and unshaded areas represent normal Pacific oceanic crust. Shaded areas represent volcanic edifices with thickened crusta sections, as well as the younger areas beyond the Pacific subduction zones.

dried and weighed before processing for the quantitative calculation of faunal abundances. The samples were processed only with pure water or a water-Calgon solution and washed over a $63-\mu \mathrm{m}$ screen. All specimens of agglutinated foraminifers in the fraction larger than 63 $\mu \mathrm{m}$ were completely picked and counted. Distribution charts were produced for each site (Tables 1-4). A problem for the quantitative treatment of abyssal agglutinated foraminiferal assemblages is the generally high abundance of fragmented tests. For this study larger fragments of multichambered Haplophragmoides and Paratrochamminoides, any single chamber of uniserial Hormosina ovulum or $H$. gigantea, and any fragment of tubular forms were counted as one individual.

\section{BIOSTRATIGRAPHY}

Turonian-Santonian marker species (i.e., Bulbobaculites lueckeiproblematicus, Uvigerinammina jankoi, and inflated involute Haplophragmoides of the $H$. pseudokirki group) are not found in agglutinated foraminiferal assemblages from the westem Pacific Ocean. This time interval is represented by chert units that are generally barren of benthic foraminifers.

In Hole $801 \mathrm{~A}$ four stratigraphically useful benthic events were observed immediately above the top of the chert units:

1. First occurrence of Bolivinopsis parvissimus and Haplophragmoides multicamerus Acme (maximum abundance within its range) (Sample 129-801A-6R-CC; middle Campanian).

2. First occurrence of Hormosina ovulum gigantea (Sample 129801A-7R-1, 62-67 cm; lower-middle Campanian).
3. Acme of Praecystammina globigerinaeformis (Sample 129801A-7R-1, 124-129 cm).

4. First occurrence of Praecystammina globigerinaeformis and Hormosina spp. (Sample 129-801A-7R-3, 80-85 cm).

The occurrence of the zonal marker Hormosina ovulum gigantea, typical of Campanian beds in the North Atlantic and the Alpine-Carpathian mountain chain in this succession enables a reasonable biostratigraphic correlation with the agglutinated foraminiferal zonations of the western Tethys (Geroch and Nowak, 1984; Moullade et al., 1988; Kuhnt et al., in press) (Fig. 3).

The occurrence of a diverse, taxonomically distinct Haplophragmoides multicamerus acme assemblage was observed in all sites studied. This assemblage is characterized by the abundant evolute Haplophragmoides (e.g., Haplophragmoides multicamerus, H. perexplicatus-constrictus, $H$. fraudulentus, $H$. biumbilicalis) and, additionally, common Praecystammina globigerinaeformis, Bolivinopsis parvissimus, Paratrochamminoides spp., and forms of the Hormosina ovulum group. The consistent taxonomic composition of these highdiversity agglutinated foraminiferal assemblages provides evidence for a coeval benthic event, which enables correlation of the sites within the western Pacific basin.

\section{Age of Haplophragmoides multicamerus Acme Assemblages}

The assemblages of the Haplophragmoides multicamerus Acme Zone in the western Pacific are characterized by the following biostratigraphically important forms:

1. Evolute Haplophragmoides: the evolutionary line of Late Cretaceous DWAF starts with involute forms $(H$. gr. pseudokirki) after the anoxic event at the Cenomanian/Turonian boundary, and pre-Campanian Haplophragmoides assemblages are generally still dominated by involute forms (e.g., Haplophragmoides herbichi). Assemblages dominated by evolute Haplophragmoides are common only since the middle Campanian in the North Atlantic basin.

2. Common/abundant Paratrochamminoides, which are characteristic for Campanian/Maestrichtian beds in the western Tethys.

3. Bolivinopsis parvissimus, which is restricted to the middle Campanian/Maestrichtian in the North Atlantic (e.g., Hole 543A, Hemleben and Troester, 1984; Site 386, Kuhnt and Moullade, 1991).

4. The most reliable biostratigraphic markers are forms of the Hormosina ovulum group. The Hormosina populations of Holes $800 \mathrm{~A}$ and 801 A include Hormosina gigantea, which is a reliable marker species of lower Campanian to middle/upper Maestrichtian strata with a distinct acme in the middle Campanian in the North Atlantic and Alpine-Carpathian mountain chain (Geroch and Nowak, 1984; Moullade et al., 1988; Kuhnt et al., in press).

In summary, we propose a middle Campanian age for the acme of Haplophragmoides in the western Pacific.

\section{CALIBRATION TO MAGNETOSTRATIGRAPHY}

In Hole $800 \mathrm{~A}$ the base of the early Campanian reversed interval 33R has been identified (Shipboard Scientific Party, 1990a) within Section 129-800A-7R-1, at about $50 \mathrm{mbsf}$. No reversed intervals have been identified in Core 129-800A-6R or higher. Thus, the top of the reversed interval 33R is between Sections 129-800A-7R-1 and 129$800 \mathrm{~A}-6 \mathrm{R}-\mathrm{CC}$ (i.e., between 40.3 and $50 \mathrm{mbsf}$ ). This is about 10.1 to $19.8 \mathrm{~m}$ below the marker depth of Haplophragmoides multicamerus acme, which we observed in samples $129-800 \mathrm{~A}-5 \mathrm{R}-1,15-20 \mathrm{~cm}$, and $129-800 \mathrm{~A}-5 \mathrm{R}-\mathrm{CC}$, at 30.05 and $30.35 \mathrm{mbsf}$, respectively. 


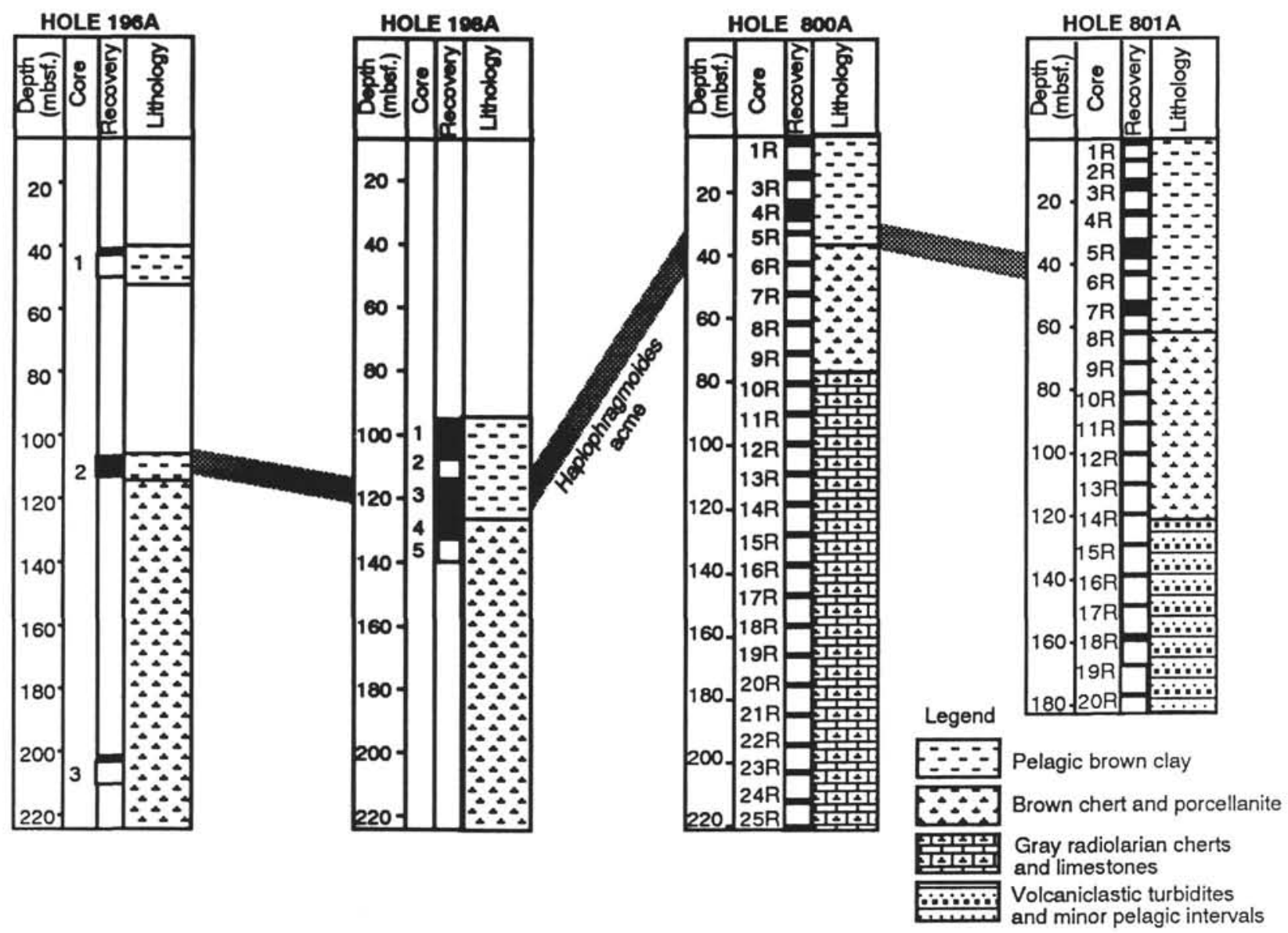

Figure 2. Core recovery and simplified lithology of the studied DSDP/ODP holes with the position of the evolute Haplophragmoides Acme correlation level.

In Hole 801A two reversed intervals above the mid-Cretaceous long normal zone are identified (Shipboard Scientific Party, 1990b). The lower of these two intervals is situated in Section 129-801A-7RCC. The upper reversed interval is in Section 129-801A-7R-4, $30 \mathrm{~cm}$, about only $15 \mathrm{~cm}$ above the lower reversed interval. The acme of Hormosina gigantea, which is a reliable biostratigraphic marker for Campanian strata in the North Atlantic Ocean, was observed in Sample 129-801A-7R-1, 62-67 cm. According to agglutinated foraminiferal biostratigraphy, both reversed intervals in Core 129801A-7R may represent the reversed part of Chron 33. These reversed intervals are situated about $4.9 \mathrm{~m}$ below the acme of Haplophragmoides multicamerus, which we observed in Samples 129-801A-7R$1,4-9 \mathrm{~cm}$, and 129-801A-6R-CC.

Sedimentation rates for Upper Cretaceous sediments are about 5.1 $\mathrm{m} / \mathrm{m} . \mathrm{y}$. at Hole $800 \mathrm{~A}$ and about $2.4 \mathrm{~m} / \mathrm{m}$.y. at Site 801 (Shipboard Scientific Party, 1990b). This implies that the Haplophragmoides multicamerus Acme would be either about 2-4 m.y. younger (Hole $800 \mathrm{~A}$ ) or $2.1 \mathrm{~m}$.y. (Hole $801 \mathrm{~A}$ ) younger than the top of the Chron 33R interval. This implies a consistent late middle Campanian age for the Haplophragmoides multicamerus Acme event.

\section{PALEOECOLOGY}

\section{Quantitative Changes}

A general trend is apparent in the foraminiferal diversity and density of the Late Cretaceous abyssal western Pacific (Figs. 4-7). A single, pronounced peak characterizes the evolution of species diver- sity, which is reflected by foraminiferal density at all sites studied. Hole 196A (Fig. 4) has its maximum diversity and density in Section 196A-2-1. Diversity and density decline through Sections 20-196A2-2 through 20-196A-2-4, and no foraminifers were recorded from deeper levels in this core. At Hole 198A (Fig. 5), foraminiferal diversity and density is lowest in Sections 20-198A-3-2 through 20-198A-3-4, but increases in Section 20-198A-3-5 through Sample 20-198A-4-2, 120-125 cm. Samples from greater depths, in Core 20-198A-4, did not contain any foraminifers. Density and diversity are low in samples from Core 129-800A-4R (Fig. 6), but reach a peak in Sample 129-800A-5R-1, 15-20 cm. In Sample 129-800A-5R-CC, density and diversity values are again low. Site 801 (Fig. 7) shows low values of diversity and density in samples from Core 129-801 A4R. In Core 129-801A-5R diversity is also low, but density shows a general increase down-section. Sample 129-801A-5R-5, 4-9 cm, has a sharp peak in density (about 35 specimens per gram of sediment), although diversity remains relatively low ( 5 species). This peak is due to the high abundance of tubular agglutinated forms of the Rhizammina/Dendrophrya complex. Diversity and density reach a peak in Sample 129-801A-7R-1, $4-9 \mathrm{~cm}$.

\section{Assemblage Types}

Foraminiferal assemblages of low diversity typically contain single or few species of such genera as Rhizammina, Dendrophrya, Hormosina, Hyperammina, Glomospira, and Paratrochamminoides, whereas the high-diversity assemblages are characterized by 
Table 1. Distribution of Upper Cretaceous agglutinated benthic foraminifers, Hole 196A.

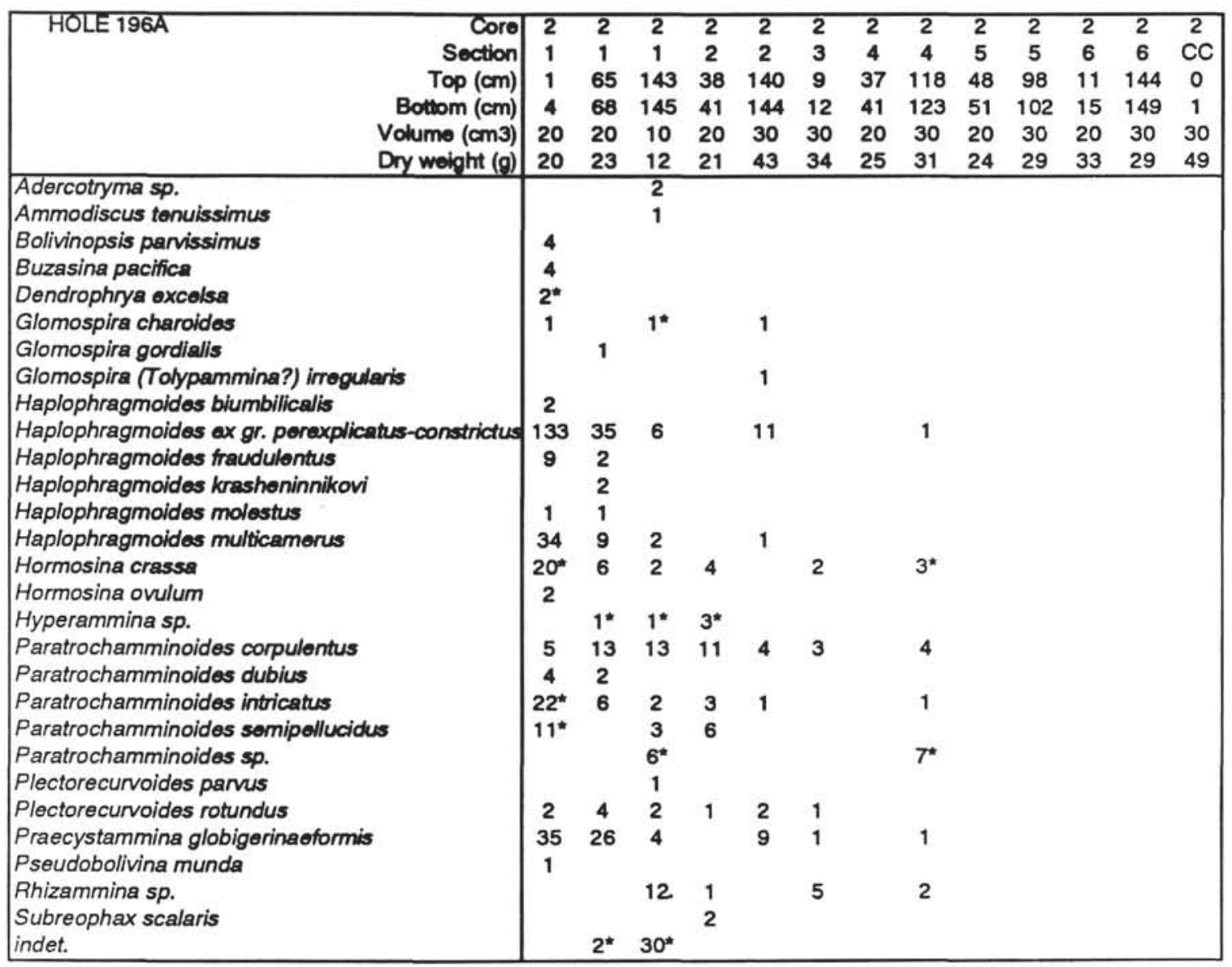

\begin{tabular}{|l|ccccccccccccc|}
\hline Total agglutinated foraminifers (oxcl. framents) & 237 & 107 & 50 & 28 & 30 & 12 & 0 & 9 & 0 & 0 & 0 & 0 & 0 \\
Faunal density (specimens per gram sediment) & 12 & 4.6 & 4.3 & 1.3 & 0.7 & 0.4 & 0 & 0.3 & 0 & 0 & 0 & 0 & 0 \\
Diversity (number of species) & 14 & 12 & 12 & 7 & 8 & 5 & 0 & 5 & 0 & 0 & 0 & 0 & 0 \\
\hline
\end{tabular}

* including fragments

Bolivinopsis parvissimus, Buzasina pacifica, Pseudobolivina munda, Praecystammina globigerinaeformis, and several species of Paratrochamminoides and Haplophragmoides. It is apparent that the lowest diversity assemblages are associated with biosiliceous sediments (e.g., with the radiolarian-rich sediments of Sections 129-801A-7R-3 and 129-801-7R-4), whereas the higher diversity assemblages are from residues with little or no biosiliceous components. Similar relationships were observed between foraminiferal biofacies and sediment type in the North Atlantic, in which the high- and low-diversity assemblages were termed "Biofacies A" and "Biofacies B," respectively (Kuhnt et al., 1989).

\section{Distribution of Faunal Groups}

Three distinct groups of agglutinated foraminifers can be discriminated in our material according to their test morphology and from life positions and feeding habits (Jones and Charnock, 1985):

1. Tubular forms and ammodiscids - epifaunal suspension or detritus feeders.
2. Small, abyssal, thin-walled smooth multichambered morphotypes - infaunal detrital/bacterial scavengers with the ability to survive under extreme oligotrophic conditions by such mechanisms as metabolizing protoplasm during resting phases or bacterial encystment (Gooday, 1990).

3. Hyperammina, Hormosina, and Paratrochamminoides group - probably infaunal detrital/bacterial scavengers and/or passive deposit-feeders.

Glomospira charoides and Praecystammina globigerinaeformis seem to occur within the latter two groups.

In the sections studied from the western Pacific group 2 is represented in larger numbers only during the short interval of the Haplophragmoides multicamerus Acme. Group 3 occurs immediately above the biosiliceous sedimentation in the lower Campanian, persists as a "background" fauna during the $H$. multicamerus Acme, and forms a major constituent of the low-diversity assemblages following the $H$. multicamerus Acme. Group 1, which is most dependent on a sufficient supply of detritic food particles from the ocean surface, dominates the assemblages above the H. multicamerus Acme (e.g., Core 129-801A-5R). 
Table 2. Distribution of Upper Cretaceous agglutinated benthic foraminifers, Hole 198A.

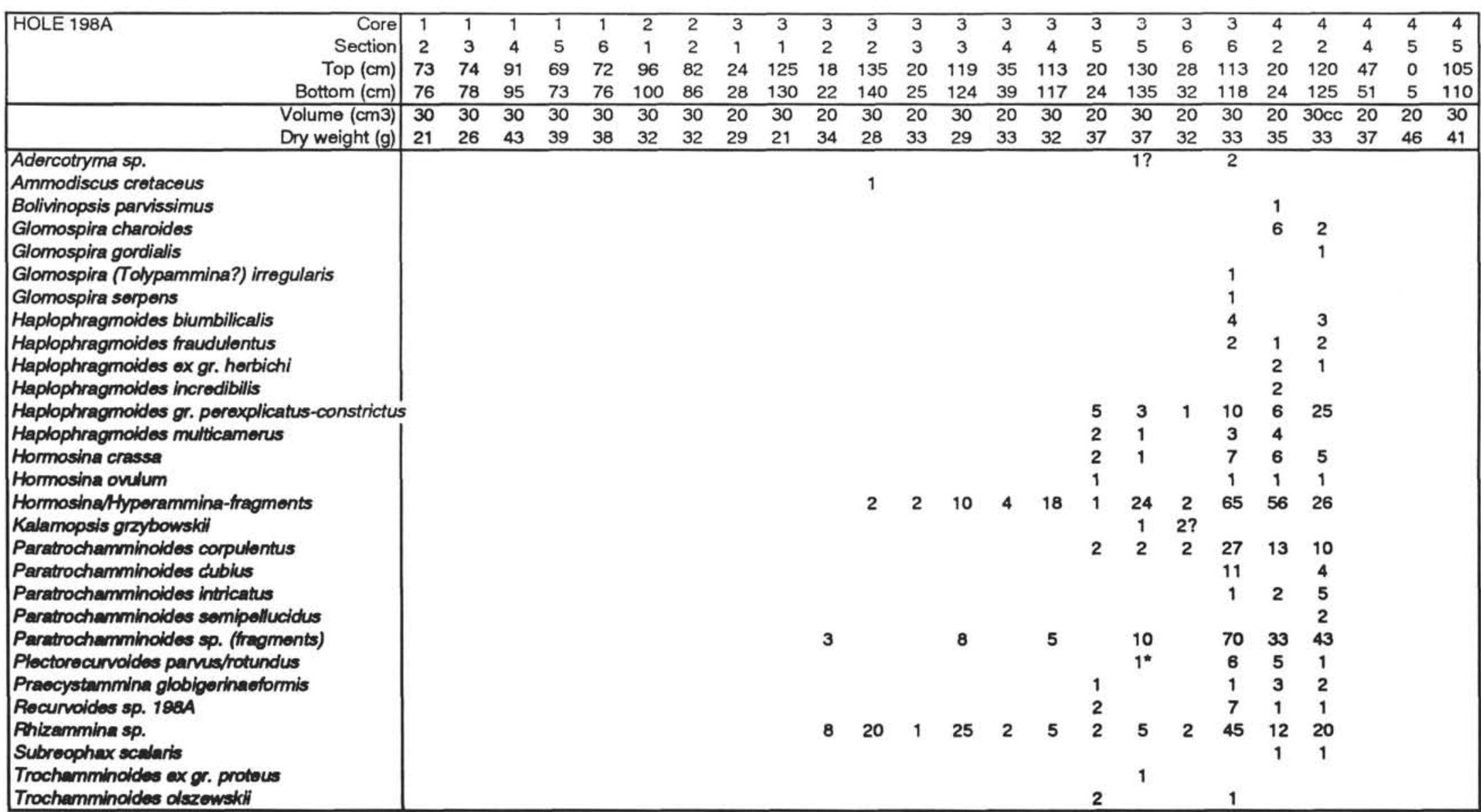

\section{Radiolarian bloficclos}

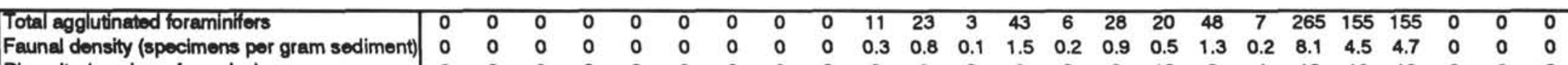

Diversity (number of species) 
Table 3. Distribution of Upper Cretaceous agglutinated benthic foraminifers, Hole 800A.

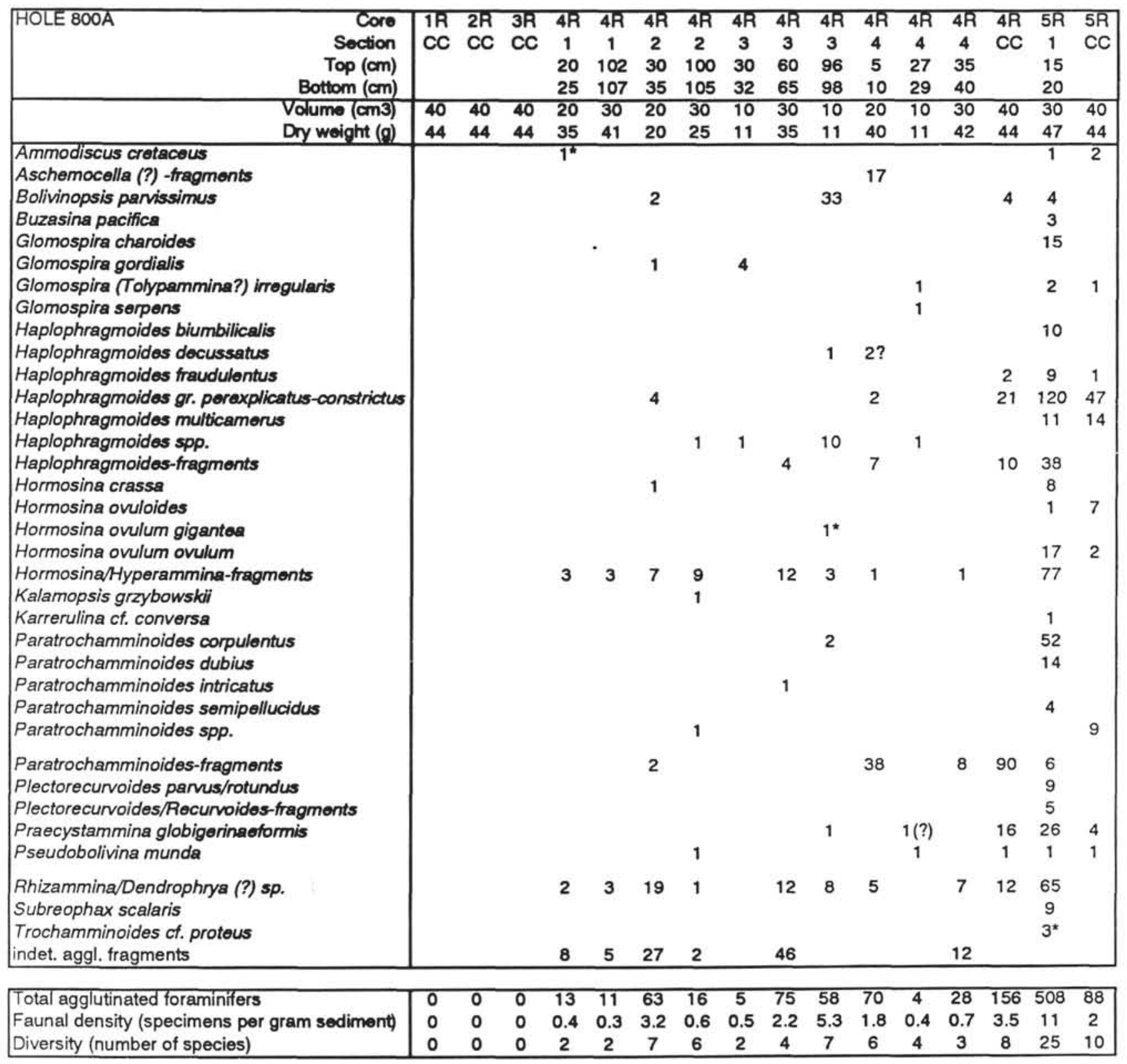

Note: For shipboard samples, we calculated $1 \mathrm{~cm} 3=1.1 \mathrm{~g}$.

From these observations it seems that changes in surface productivity may have controlled the evolution of abyssal agglutinated foraminifers in the western Pacific basin during the Late Cretaceous. The enhanced productivity of siliceous plankton during the mid-Cretaceous was probably followed by a continuous decrease in surface productivity of siliceous plankton during the middle Campanian. The abyssal assemblages of the late middle Campanian to late Campanian $H$. multicamerus Acme Zone resemble benthic populations beneath oceanic oligotrophic gyres. The recurrence of suspension/detritus-feeding opportunists in the uppermost Cretaceous may indicate again the slightly increased productivity of the surface waters. A drastic decrease of agglutinated foraminifers was observed in the uppermost Maestrichtian or lower Paleogene. This trend parallels the trend observed by Moullade et al. (1988) in the North Atlantic. However, insufficient core recovery and lack of biostratigraphic control do not allow a correlation of this observation to the Cretaceous/Paleogene boundary event.

\section{COMPARISON TO THE EVOLUTION OF ABYSSAL AGGLUTINATED FORAMINIFERS IN THE NORTH ATLANTIC OCEAN}

Diversity trends of Late Cretaceous abyssal agglutinated foraminifers were compared for DSDP Holes 398D and 386 in the North Atlantic and the western Pacific Holes 196A, 198A, 800A and 801A (Fig. 8). The diversity trends in North Atlantic sites are probably related to two Late Cretaceous biosiliceous events: the Cenomanian/Turonian boundary event (CTBE) and the early Campanian event (ECE) (Kuhnt et al., 1989). The diversity trends of the abyssal assemblages in the western Pacific also show low diversities in the 
Table 4. Distribution of Upper Cretaceous agglutinated benthic foraminifers, Hole 801A.

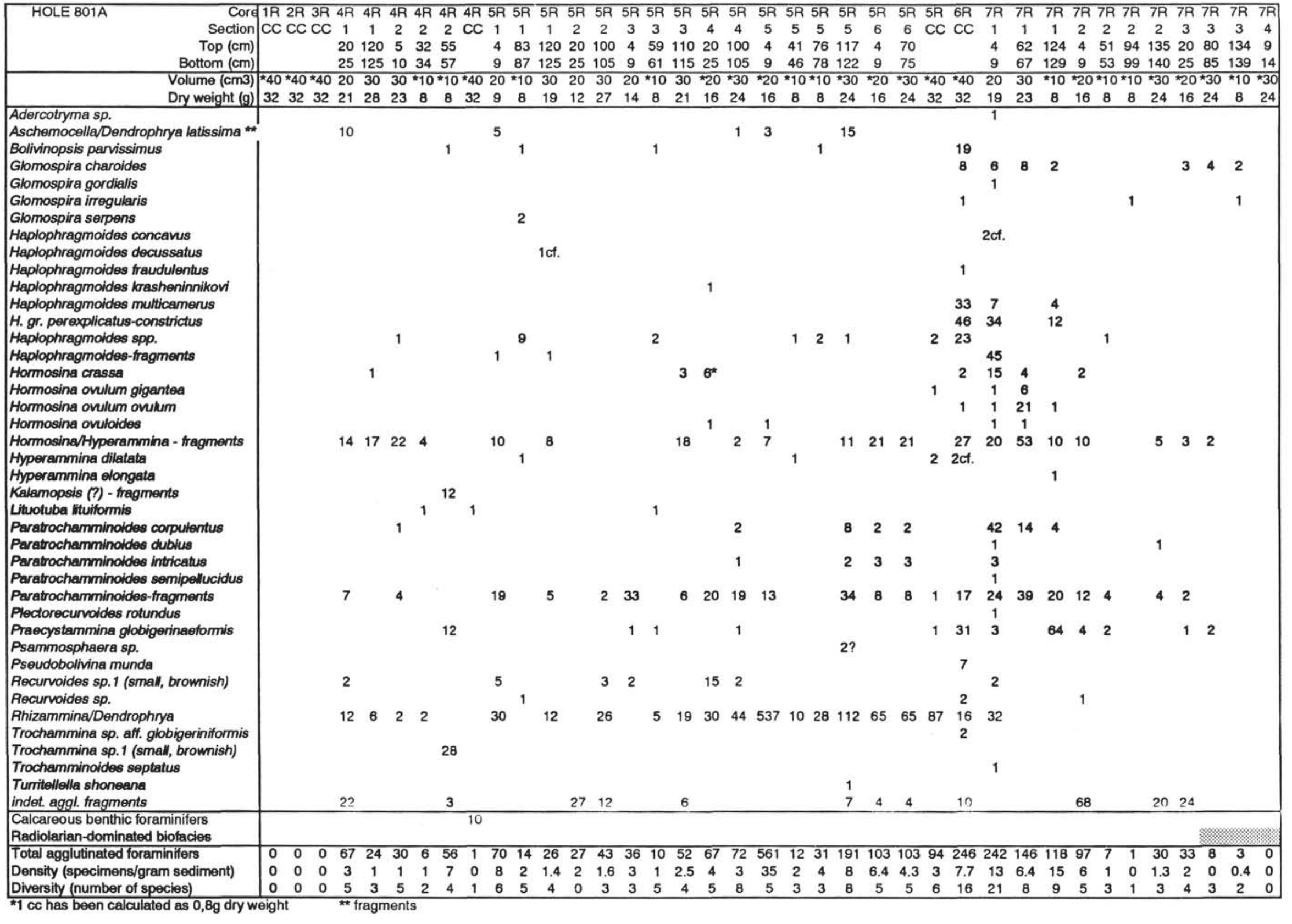




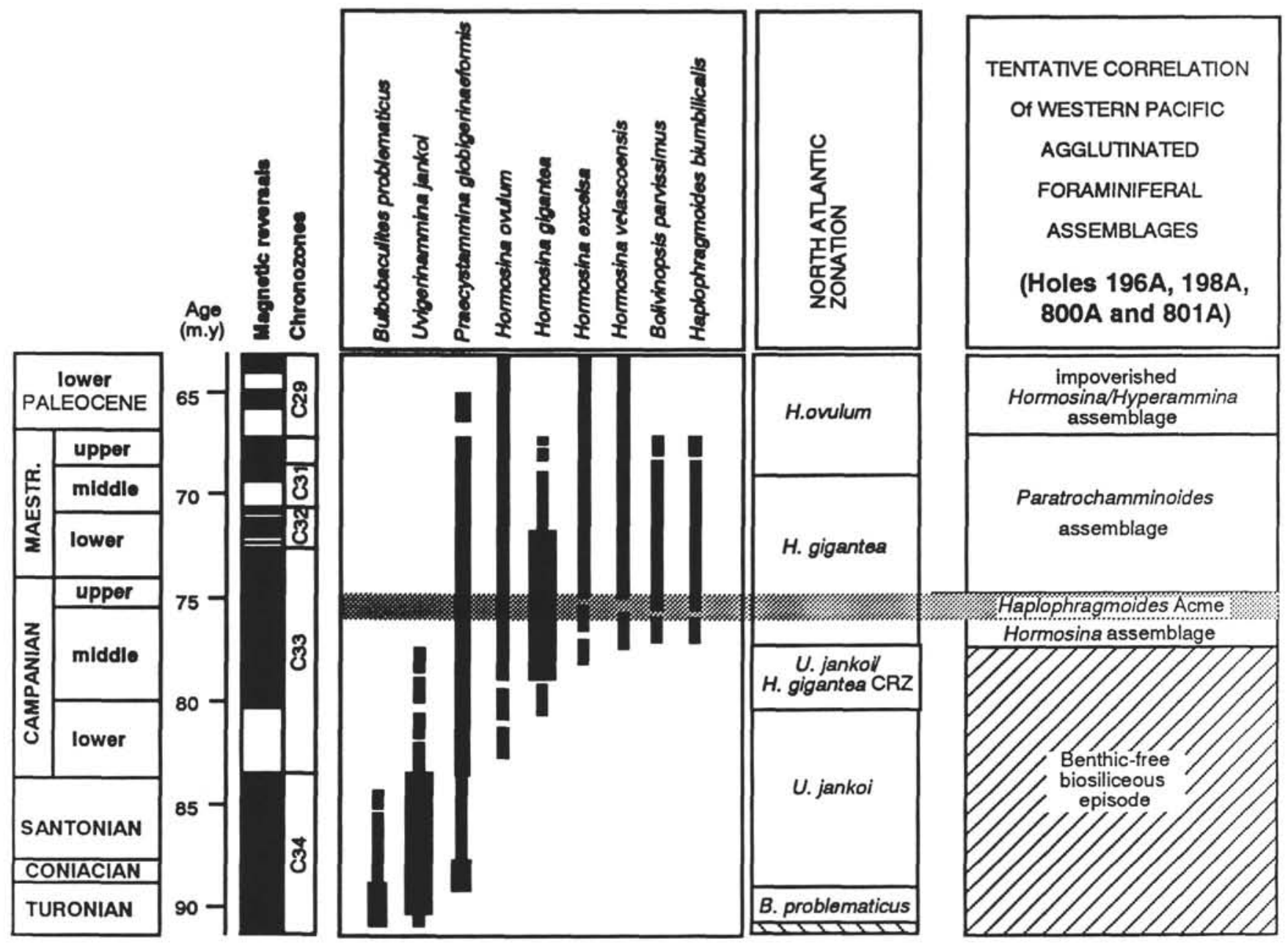

Figure 3. Biochronology of western Pacific foraminiferal assemblages as determined from the ranges of North Atlantic/western Tethyan marker species occurring in the assemblages.

lower Campanian at all sites. This appears to be related to the transition from biosiliceous to clay sedimentation. The higher diversity assemblages in the western Pacific during the Haplophragmoides spp. Acme characterize pelagic clays. The low diversities in the upper parts at Hole $800 \mathrm{~A}$ and $801 \mathrm{~A}$ occur probably in the Paleocene.

\section{CONCLUSIONS}

The majority of the observed Upper Cretaceous DWAF are cosmopolitan species, which occur in the western Pacific, North Atlantic, and western Tethyan oceans. Several biostratigraphic markers (e.g., Hormosina-Haplophragmoides and Paratrochamminoides lineages) seem to have comparable stratigraphic ranges within these basins. However, differences in quantitative DWAF distribution in time between the North Atlantic and the western Pacific are obvious: the oldest typical abyssal assemblages are observed in the North Atlantic in the Turonian and those in the western Pacific are as late as late early Campanian. There is only one comparatively short-term episode of abundant and diversified DWAF in the middle Campanian of the western Pacific, whereas in the North Atlantic rich DWAF assemblages are common throughout the entire Upper Cretaceous, following the Cenomanian/Turonian boundary event. Mid-Cretaceous biosiliceous episodes, which were hostile to DWAF, have different intensities and durations. They cover the entire Turonian-lower Campanian interval in the western Pacific, whereas they are restricted to two short episodes at the Cenomanian/Turonian boundary and within the lower Campanian in the North Atlantic.

\section{ACKNOWLEDGMENTS}

We are grateful to the Ocean Drilling Program for providing us with the sample material for this study. We especially appreciate the fast response to our additional post-cruise sample request for material from Sites 196 and 198. We thank W. A. Berggren and an anonymous reviewer for their comments on this manuscript. W. G. Wightman thanks the Ocean Drilling Program for inviting him to participate on Leg 129 aboard JOIDES Resolution. W. G. Wightman benefited from a NSERC Collaborative Special Project Grant awarded to F. M. Gradstein. W. Kuhnt was supported by a postdoctoral fellowship from the Killam Trust of Dalhousie University.

\section{TAXONOMIC NOTES}

The alphabetic listing of species includes the original and present name of the species. Full synonymies/references are not given, although references to certain stratigraphically important species are provided.

\section{Adercotryma sp. \\ (Pl. 2, Fig. 5)}

?Trochammina gyroidinaeformis Krasheninnikov, 1974, p. 641, pl. 5, figs. $7 \mathrm{a}-\mathrm{c}, 8 \mathrm{a}-\mathrm{c}, 9 \mathrm{c}$

?Trochammina gyroidinaeformis Krasheninnikov, Hemleben and Troester, 1984 , p. 522 , pl. 4 , figs. $11-13$.

?Trochammina gyroidinaeformis Krasheninnikov, Moullade et al., 1988, pl. 8 , figs. $4-6$. 
Ammodiscus cretaceus (Reuss, 1845)

$$
\text { (Pl. 1, Fig. 6) }
$$

Operculina cretacea Reuss, 1845 , p. 35 , pl. 13 , figs. 64,65 .

Ammodiscus cretaceus (Reuss), Hemleben and Troester, 1984, p. 517, pl. 1, fig. 17.

Ammodiscus cretaceus (Reuss), Krasheninnikov and Pflaumann, 1978, p. 569, pl. 2 , fig. 7

Ammodiscus cretaceus (Reuss), Moullade et al., 1988, p. 363, pl. 1, fig. 7.

Ammodiscus cretaceus (Reuss), Kuhnt, 1990, pl. 1, figs. 2, 3.

\section{Ammodiscus tenuissimus Grzybowski, 1898}

(Pl. 1, Fig. 7)

Ammodiscus tenuissimus Grzybowski, 1898, p. 282, pl. 10, fig. 35. Ammodiscus planus Loeblich, Kaminski et al., 1988, p. 185, pl. 3, fig. 13. Ammodiscus planus Loeblich, Kuhnt, 1990, pl. 1, fig. 5.

Remarks. We use this name for the small and thin-walled ammodiscids, which occur rarely in the material from the western Pacific. These forms agree well with the type material in the Grzybowski collection. The deep-sea forms differ from A. planus from the Turonian shallow-marine pepper shales in having fewer but slightly broader whorls.

\section{Aschemocella/Dendrophrya latissima fragments}

(Pl. 1, Figs. 2, 3)

?Aschemonella carpathica Neagu, 1964, pp. 582-586, text-figs. $2.2-4,3.1-3$, 4.1-6.

?Aschemocella carpathica (Neagu), Kuhnt and Kaminski, 1990, p. 464, pl. 2, figs. a-e.

?Dendrophrya latissima Grzybowski, 1898, p. 17, pl. 10, fig. 8.

? Psammosiphonella anglesiaensis (Crespin), Krasheninnikov and Pflaumann, 1977 , p. 567 , pl. 1 , figs. $3-4$.

?Dendrophrya latissima Grzybowski, Kaminski et al., 1988, p. 182, pl. 1, fig. 6.

Remarks. The specimens occur as fragments of large, flattened agglutinated tests. The test wall is coarsely agglutinated from quartz, mica, and abundant cement. Some of the fragments allow recognition of an ovoid chamber outline. Fragments of two species, Dendrophrya latissima and Aschemocella carepathica, are probably included in this group.

\section{Bolivinopsis parvissimus Krasheninnikov, 1973}

(Pl. 3, Fig. 11)

Bolivinopsis parvissimus Krasheninnikov, 1973, p. 210, pl. 2, figs. 8, 9.

Bolivinopsis parvissimus Krasheninnikov, Hemleben and Troester, 1984, p. 517. pl. 4 , fig. 1.

Buzasina pacifica (Krasheninnikov, 1973)

$$
\text { (Pl. 1, Fig. 8) }
$$

Labrospira pacifica Krasheninnikov, 1973, p. 209, pl. 2, figs. 4a, b, 5a, b.

Labrospira pacifica Krasheninnikov, Krasheninnikov, 1974, p. 637, pl. 3 , figs. 1a, b, 2a, b.

Labrospira pacifica Krasheninnikov, Gradstein and Berggren, 1981, p. 260, pl. 9, figs. 9, 10.

Labrospira pacifica Krasheninnikov, Hemleben and Troester, 1984, p. 520. pl. 3 , fig. 8 .

Labrospira pacifica Krasheninnikov, Moullade et al., 1988, p. 365, pl. 7, fig. 8.

Remarks. Buzasina pacifica differs from B. inflata (Krasheninnikov, 1974) in possessing less inflated chambers and in its more compressed outline. We assign these species to the genus Buzasina, in accordance with the usage in Loeblich and Tappan (1988).

\section{Glomospira charoides (Jones and Parker, 1860)}

$$
\text { (PI. 1, Fig. 9) }
$$

Trochammina squamata Jones and Parker var. charoides Jones and Parker, 1860 , p. 304.

Glomospira charoides (Jones and Parker), Kaminski et al., 1988, p. 185, pl. 3, figs. 14-15.
Glomospira charoides (Jones and Parker), Moullade et al., 1988, p. 363, pl. 1, fig. 6 .

$$
\text { Glomospira gordialis (Jones and Parker, 1860) }
$$$$
\text { (P1. 1, Fig. 10) }
$$

Trochammina squamata Jones and Parker var. gordialis Jones and Parker, 1860 , p. 304

Glomospira gordialis (Jones and Parker), Hemleben and Troester, 1984, p. 518 , pl. 1, fig. 20.

Glomospira gordialis (Jones and Parker), Kaminski et al., 1988, p. 185, pl. 3, fig. 17.

Glomospira gordialis (Jones and Parker), Moullade et al., 1988, p. 363, pl. 1, fig. 4.

Glomospira gordialis (Jones and Parker), Kuhnt, 1990, pl.1, figs. 9, 10.

Glomospira (Tolypammina?) irregularis (Grzybowski, 1898)

$$
\text { (Pl. 1, Fig. 11) }
$$

Ammodiscus irregularis Grzybowski, 1898, p. 285, pl. 11, figs. 2, 3.

Glomospira? irregularis (Grzybowski), Hemleben and Troester; 1984, p. 519 , pl. 1, fig. 22.

Glomospira irregularis (Grzybowski), Kaminski et al., 1988, p. 185, pl. 3, figs. 20-21.

Glomospira (Tolypammina?) irregularis (Grzybowski), Kuhnt, 1990, pl. 1, fig. 12.

Glomospira serpens (Grzybowski, 1898)

(Pl. 1, Fig. 12)

Ammodiscus serpens Grzybowski, 1898, p. 285, pl. 10, figs. 31-33.

Glomospira serpens (Grzybowski), Hemleben and Troester, 1984, p. 519, pl. 1, fig. 23

Glomospira serpens (Grzybowski), Moullade et al., 1988, p. 363, pl. 1, fig. 2, 3. Glomospira serpens (Grzybowski), Kuhnt, submitted, pl. 1, fig. 4.

\section{Haplophragmoides biumbilicalis Krasheninnikov, 1973}

(P1. 2, Figs. 6-7)

Haplophragmoides biumbilicalis Krasheninnikov, 1973, p. 208, pl, 1, figs. $3 \mathrm{a}-\mathrm{b}, 4$.

Remarks. The umbilicus is narrow, but deep; the final whorl has a distinct shoulder bordering the umbilicus. It differs from $H$. molestus and $H$. perexplicatus-pervagatus by its more inflated test with a broadly rounded peripheral margin and by its deep, conical umbilicus.

\section{Haplophragmoides cf. concavus (Chapman, 1892)} (Pl. 2, Fig. 8)

Trochammina concava Chapman, 1892, p. 327, pl. 6, fig. 14a-b. Haplophragmoides cf. concava (Chapman), Geroch, 1960, p. 127, pl. 5, fig. 2. Haplophragmoides cf. concavus (Chapman), Moullade et al., 1988, p. 365, pl. 8, figs. 8,9 .

Remarks. The completely flattened, finely agglutinated tests have three to five chambers in the last whorl. It is comparable with $\mathrm{H}$. walteri (Grzybowski) in its narrow compressed outline, but with fewer chambers in the last whorl and a lobulated periphery. In our material specimens of $H$. cf. concavus have a whitish coloration of the test, which differs from the other typically brown colored species of Haplophragmoides.

\section{Haplophragmoides decussatus Krasheninnikov, 1973}

$$
\text { (PI. 2, Fig. 9) }
$$

Haplophragmoides decussatus Krasheninnikov, 1973, pp. 208-209, pl. 2, fig. $3 \mathrm{a}, \mathrm{b}$.

Haplophragmoides decussatus Krasheninnikov, Krasheninnikov, 1974, pl. 1, fig. $6 \mathrm{a}, \mathrm{b}$.

$$
\text { Haplophragmoides fraudulentus Krasheninnikov, } 1973
$$

(Pl. 2, Figs. 10, 11)

Haplophragmoides fraudulentus Krasheninnikov, 1973, p. 207, pl. 1, fig. 9a, b. 
Haplophragmoides fraudulentus Krasheninnikov, Krasheninnikov, 1974. p. 634 , pl. 1, figs. 1a, b, $2 a$.

Haplophragmoides fraudulentus Krasheninnikov, Hemleben and Troester, 1984, p. 519, pl. 2, figs. 19, 20.

Haplophragmoides fraudulentus Krasheninnikov, Moullade et al., 1988, p. 365 , pl. 5 , fig. 7,8 .

Remarks. The test is small and evolute with a broad, shallow umbilicus. The last whorl has six to seven spherical chambers, separated by deep radial to slightly curved sutures.

\section{Haplophragmoides ex gr. herbichi Neagu, 1968}

$$
\text { (Pl. 2, Fig. 12) }
$$

Haplophragmoides herbichi Neagu, 1968, p. 238, pl. 1, figs. 9-12.

Haplophragmoides bulloides Beissel, Krasheninnikov, 1974, p. 636, pl. 1, figs. $9 \mathrm{a}, 9 \mathrm{~b}, 10$, and $11 \mathrm{~b}$.

Haplophragmoides bulloides Beissel, Moullade et al., 1988, p. 363, pl. 6, fig. 3. Haplophragmoides ef. herbichi Neagu, Moullade et al., 1988, p. 365, pl. 6, figs. 1,2 .

Remarks. The tests are planispiral coiled and involute with 9-10 chambers in the last whorl. The peripheral margin is rounded and the radial sutures are completely flush (thus giving the test an appearance like a nautilus). A very narrow, deep umbilicus is present. The aperture is a narrow slit at the base of the final chamber. The species is rare in our material, but it occurs frequently in the Turonian to Santonian of the North Atlantic Ocean (Moullade et al., 1988; Kuhnt and Moullade, in press), in the Turonian/Coniacian of the Rumanian eastern Carpathians (Neagu, 1990), and in the Turonian/Santonian of the Indian Ocean (Krasheninnikov, 1974). Thus, it may represent an earlier stage in the evolution of Late Cretaceous abyssal Haplophragmoides. The few specimens we observed in Core 129-198A-4R are morphologically close to those from the Rumanian Eastern Carpathians and the Atlantic Ocean, however, the rare occurrence and the poor preservation of these specimens makes it preferable to place them in a $H$. herbichi group.

\section{Haplophragmoides incredibilis Krasheninnikov, 1974}

(Pl. 2, Figs. 13-14.)

Haplophragmoides incredibilis Krasheninnikov, 1974, pl. 2, figs. 5a-c.

Haplophragmoides krasheninnikovi nomen novum (Pl. 2, Fig. 15; Pl. 3, Fig. 1)

Haplophragmoides multiformis Krasheninnikov, 1974, pl. 2, figs. 1a, b, 2a, b.

Remarks. The test is small to medium in size and strongly involute with four subtriangular or trapeziform chambers in the last whorl. The lateral outline is a somewhat elongate oval, and is slightly lobulate. It is restricted to the abyssal environment and rare in the material from the western Pacific.

This characteristic species was first described from the Indian Ocean as Haplophragmoides multiformis by Krasheninnikov (1974). Because this name is a junior homonym of Haplophragmoides multiformis Akimets, 1966, the name must be rejected under Article 59 of the International Code of Zoological Nomenclature (ICZN). As no junior synonym exists as a replacement name, we propose the new name Haplophragmoides krasheninnikovi after V. Krasheninnikov, who first described this form as a valid species.

\section{Haplophragmoides molestus Krasheninnikov, 1973}

$$
\text { (PI. 3, Fig. 2) }
$$

Haplophragmoides molestus Krasheninnikov, 1973, p. 208, pl. 1, fig. 8a, b.

Remarks. The test is involute, moderately compressed, with 5 to 6 chambers in the last whorl, increasing gradually in size as added. The umbilicus is narrow and flat, chambers are almost united in the center, and inner whorls are not observed. The wall is very finely agglutinated, siliceous, and glassy, with a smooth surface. It differs from $H$. perexplicatus in its narrow and flat umbilicus with inner whorls not visible. The species is very rare in our material and has been included in the Haplophragmoides perexplicatus-constrictus group in the range charts.

Haplophragmoides multicamerus Krasheninnikov, 1973

$$
\text { (Pl. 3, Figs. 3-5) }
$$

Haplophragmoides multicamerus Krasheninnikov, 1973, p. 207, pl. 1, figs. 1a, b, 2a, b. Krasheninnikov, 1974, p. 635, pl. 1, fig. 4a, b. Moullade et al. 1988 , p. 365 , pl. 5 , figs. 1,2 .

Remarks. The test is small and evolute, with a wide, but shallow, umbilicus; the last whorl consists of seven to 10 narrow chambers.

\section{Haplophragmoides ex gr. perexplicatus-constrictus Krasheninnikov, 1973 (Pl. 3, Figs. 6-8)}

Haplophragmoides perexplicatus Krasheninnikov, 1973, p. 208, pl. 1, figs. $6 a, b$.

Haplophragmoides pervagatus Krasheninnikov, 1973, p. 208, pl. 1, fig. 7a, b. Haplophragmoides perexplicatus Krasheninnikov, Krasheninnikov, 1974, p. 635 , pl. 1, figs. 5a, b.

Haplophragmoides perexplicatus Krasheninnikov, Moullade et al., 1988, p. 365 , pl. 5, fig. 4-6.

Haplophragmoides constrictus Krasheninnikov, 1973, pp. 207-208, pl. 1 , figs. $5 \mathrm{a}, \mathrm{b}$.

Haplophragmoides constrictus Krasheninnikov, Krasheninnikov, 1974, p. 635. pl. 1, figs. 3a, b.

Haplophragmoides constrictus Krasheninnikov, Moullade et al., 1988, p. 365, pl. 4, figs. 7-9.

Remarks. Haplophragmoides constrictus differs from $H$. perexplicatus in its slightly more evolute aspect, a very slow increase of chamber height in the process of growth, a broader umbilicus, and the lack of an elongated final chamber protruding beyond the general contour of the test. In the rich material from the western Pacific Ocean we observed many intermediate stages between forms that correspond closely to the holotypes of $H$. perexplicatus, $H$. pervagatus, and $H$. constrictus. These forms may be morphologic end-members of a continuous morphologic lineage. Thus, we did not separate single species and placed all forms of this morphologic group in Haplophragmoides ex gr. perexplictus-constrictus.

\section{Hormosina crassa Geroch, 1966}

(Pl. 1, Figs. 15, 16)

Hormosina ovulum crassa Geroch, 1966, p. 438, figs. 6(19,21-26), 7(21-23). Hormosina ovulum crassa Geroch, Hemleben and Troester, 1984, p. 520, pl. 2, figs. 8, 9.

Hyperammina cf. dilatata Grzybowski, Hemleben and Troester, 1984, p. 520, pl. 1, fig. 11.

Hormosina crassa Geroch, Moullade et al., 1988, p. 365, pl. 2, fig. 4-6.

Hormosina crassa Geroch, Kuhnt, 1990, pl. 2, fig. 5.

Remarks. Hormosina crassa is more coarsely agglutinated than other species of the genus Hormosina. The chambers are ovoid to spherical in outline and have thick connections. Our specimens are generally represented by single chambered fragments.

\section{Hormosina ovuloides (Grzybowski, 1901)}

$$
\text { (Pl. 2, Fig. 1) }
$$

Reophax ovuloides Grzybowski, 1901, p. 223, pl. 8, fig. 3.

Hormosina ovuloides (Grzybowski), Hemleben and Troester, 1984, p. 520 , pl. 2 , fig. 6 .

Hormosina ovulum (Grzybowski), Moullade et al., 1988, p. 365, pl. 2, figs. 7-8. Hormosina ovuloides (Grzybowski), Moullade et al., 1988, p. 365, pl. 2, fig. 10. Hormosina ovuloides (Grzybowski), Kaminski et al., 1988, p. 186, pl. 2, figs. 3-4.

Remarks. This species has chambers that are more elongated and asymmetrical than those of Hormosina ovulum. The connections between the chambers are relatively broad. The wall is thick and finely agglutinated. Some of our specimens may be transitional forms to $H$. excelsa.

\section{Hormosina ovulum gigantea Geroch, 1960} (PI. 1, Fig. 17)

Hormosina ovulum (Grzybowski) var. gigantea Geroch, 1960, p. 43, pl. 2, figs. 18-19.

Hormosina ovulum gigantea Geroch, Geroch and Nowak, 1984, pl. 1, fig. 20; pl. 5, figs. 15-16. 
Hormosina gigantea Geroch, Moullade et al., 1988, p. 365, pl. 2, fig. 11. Hormosina ovulum gigantea Geroch, Kuhnt and Kaminski, 1990, p. 474, pl. I, figs. $a-b$.

Remarks. This species differs from Hormosina ovulum (Grzybowski) in the more globular outline of the chambers and larger size. In the western Pacific material, we observed both compressed (e.g., Sample 129-801A-5R-CC) and undeformed specimens (e.g., Sample 129-801A-7R-1, 62-67 cm). Because the compressed forms are found at shallower depth than the undeformed specimens within the same core, this feature is probably not related to differing burial histories. We assign this feature to different wall thicknesses due to differing environmental conditions (e.g., detrital food supply).

\section{Hormosina ovulum ovulum (Grzybowski, 1898)}

$$
\text { (P1. 2, Fig. 2) }
$$

Reophax ovulum Grzybowski, 1896, p. 276, pl. 8, figs. 19-21.

Hormosina ovulumovulum (Grzybowski), Kuhnt and Kaminski, 1990, pp. 474-475, pl. 1, figs. c-e.

Remarks. This species differs from Hormosina ovulum gigantea in its smaller size $(200-400 \mu \mathrm{m})$ and more elongated chambers. Although intermediate forms exist, Hormosina ovulum ovulum has a wider stratigraphic range, from the late Lower Cretaceous to the Paleocene (Geroch, 1960; Geroch and Nowak, 1984; Moullade et al., 1988).

\section{Hyperammina dilatata Grzybowski, 1896}

$$
\text { (PI. 1, Fig. 4) }
$$

Hyperammina dilatata Rzehak, Grzybowski, 1896, pp. 274-275, pl. 8, fig. 17.

Hyperammina dilatata Grzybowski, Kaminski et al., 1988, p. 184, pl. 2, figs. 1-2.

\section{Hyperammina elongata Brady, 1884}

$$
\text { (Pl. 1, Fig. 5) }
$$

Hyperammina elongata Brady, 1884, p. 257, pl. 23, figs. 4, 7-10.

Hyperammina ex gr. elongata Brady, Hemleben and Troester, 1984, p. 520 , pl. 1, figs. 12-13.

Hyperammina elongata Brady, Kuhnt, 1988, pl. 4, fig. 3.

$$
\text { Kalamopsis grzybowskii (Dylazanka, 1923) }
$$$$
\text { (Pl. 2, Fig. 3) }
$$

Hyperammina grzybowskii Dylazanka, 1923, pp. 65-66.

Kalamopsis grzybowskii (Dylazanka), Hemleben and Troester, 1984, p. 550, pl. 2, figs. 3-5.

Kalamopsis grzybowskii (Dylazanka), Kaminski et al., 1988, p. 187, pl. 1, figs. $18-20$.

Remarks. Typical large specimens with a whitish colored wall are very rare in our material. Fragments of small brownish tubular forms with a smooth thin wall, and evidence of chamber separations are listed as Kalamopsis (?) fragments.

\section{Karrerulina cf. conversa (Grzybowski, 1901)}

$$
\text { (Pl. 4, Fig. 15) }
$$

Gaudryina conversa Grzybowski, 1901, p. 285, pl. 7, figs. 15, 16.

Plectina conversa (Grzybowski), Krasheninnikov and Pflaumann, 1978, p. 569 , pl. 3 , figs. $4 a$, b.

Plectina aff. conversa (Grzybowski), Hemleben and Troester, 1984, p. 521, pl. 4, fig. 24.

Karreriella conversa (Grzybowski), Kaminski et al., 1988, p. 196, pl. 9 , figs. 17-18b.

Plectina conversa (Grzybowski), Moullade et al., 1988, p. 365, pl. 9, figs. 1-3.

Remarks. This species occurs in our material as a single specimen with a broken end. The initial portion shows the typical features of the genus Karrerulina. Because the apertural part is broken, we are unable to decide whether this form may be included in the new genus Gerochella Neagu, 1990, which differs from Karrerulina mainly in possessing an apertural slit rather than a terminal aperture produced on an apertural neck.
Lituotuba lituiformis (Brady, 1879)

(Pl. 1, Fig. 14)

Trochammina lituiformis Brady, 1879, p. 59, pl. 5, fig. 16.

Lituotuba lituiformis (Brady), Kaminski et al., 1988, p. 190, pl. 4, figs. 14-15.

Lituotuba lituiformis (Brady), Kuhnt, 1990, pl. 1, figs. 17-18.

\section{Paratrochamminoides corpulentus Krasheninnikov, 1973}

(PI. 3, Fig. 15; Pl. 4, Fig. 1)

Paratrochamminoides corpulentus Krasheninnikov, 1973, p. 212, pl. 3, figs. 3a, b, c.

Paratrochamminoides conglobatus (Brady), Hemleben and Troester, 1984, p. 520 pl. 3, fig. 9 .

Paratrochamminoides semipellucidus Krasheninnikov, Hemleben and Troester, 1984, p. 520, pl. 3, figs. 12-14.

Paratrochamminoides sp. 2, Hemleben and Troester, 1984, p. 521, pl. 3, fig. 18.

Paratrochamminoides corpulentus Krasheninnikov, Moullade et al., 1988, p. 365 , pl. 3 , figs. 8,9 .

Remarks. The test has an elliptical outline, and the chambers are elongated. Umbilical deepenings are absent (in contrast to $P$. semipellucidus). The wall is very finely agglutinated, whitish, and smooth.

\section{Paratrochamminoides dubius (Grzybowski, 1898)}

$$
\text { (Pl. 4, Fig. 2) }
$$

Ammodiscus dubius Grzybowski, 1901, p. 274, pl. 8, figs. 12, 14.

Trochamminoides dubius (Grzybowski), Kaminski et al., 1988, p. 191, pl. 4, figs. 16-17.

Remarks. This species has an irregular planispiral or streptospiral coil. The chambers are strongly elongated, with indistinct sutures. The wall is finely agglutinated with a smooth surface.

\section{Paratrochamminoides intricatus Krasheninnikov, 1973}

$$
\text { (Pl. 4, Fig. 3) }
$$

Paratrochamminoides (?) intricatus Krasheninnikov, 1973, p. 212, pl. 3 , figs. 2a-c.

Paratrochamminoides intricatus Krasheninnikov, Krasheninnikov, 1974, p. 638, pl. 4 , figs. $2 \mathrm{a}-\mathrm{c}$.

Paratrochamminoides intricatus Krasheninnikov, Hemleben and Troester, 1984 , p. 520, pl. 3, figs. $10-11$

Remarks. The globular chambers gradually increase in size as added and are regularly coiled. This species commonly occurs as only fragments.

$$
\text { Paratrochamminoides olszewskii (Grzybowski, 1898) }
$$

Trochammina olszewskii Grzybowski, 1898, p. 286, pl. 11, fig. 6 . Trochamminoides olszewskii Grzybowski, Neagu, 1962.

Paratrochamminoides (?) semipellucidus Krasheninnikov, 1973, p. 212, pl. 3 , figs. $4 \mathrm{a}, \mathrm{b}, \mathrm{c}$.

Remarks. The test of this species has an irregular low trochospiral to almost planispiral coil, with elongated chambers. These forms have been assigned to P. semipellucidus by Krashenninikov (1973). A comparison to type material of $P$. olszewskii, which is preserved in the Grzybowski collection of the Jagiellonian University (Krakow), shows an identical test morphology of these two forms. We regard the differences in wall structure (the forms from the Pacific Ocean are thin walled and extremely fine grained) as due to ecologic variability and/or a different diagenetic history, and regard $P$. semipellucidus Krasheninnikov as a junior synonym of $P$. olzewskii Grzybowski.

\section{Plectorecurvoides parvus Krasheninnikov, 1973}

$$
\text { (Pl. 4, Fig. 6) }
$$

Plectorecurvoides parvus Krasheninnikov, 1973, p. 210, pl. 2, figs. 6a, b, c, $7 \mathrm{a}, \mathrm{b}, \mathrm{c}$.

Plectorecurvoides parvus Krasheninnikov, 1974, p. 640, pl. 5, figs. 3a,b,c. 
Plectorecurvoides rotundus Krasheninnikov, 1974

$$
\text { (Pl. 4, Fig. 7) }
$$

Plectorecurvoides rotundus Krasheninnikov, 1974, p.641, pl. 5, figs. 4a, b, c, $5 \mathrm{c}, 6 \mathrm{c}$.

Remarks. This species differs from $P$. parvus in its inflated spherical test with indistinct sutures. There are intermediate forms to $P$. parvus.

Praecystammina globigerinaeformis Krasheninnikov, 1973

$$
\text { (Pl. 4, Figs. 8-10) }
$$

Praecystammina globigerinaeformis Krasheninnikov, 1973, p. 211, pl. 3, figs. 1a, b, c, 2 .

Praecystammina globigerinaeformis Krasheninnikov, Hemleben and Troester, 1984, p. 521, pl. 4, fig. 8.

Praecystammina globigerinaeformis Krasheninnikov, Moullade et al., 1988, pp. 365-366, pl. 7, fig. 6.

\section{Pseudobolivina munda Krasheninnikov, 1973}

(Pl. 4, Fig. 5)

Pseudobolivina munda Krasheninnikov, 1973, p. 210, pl. 2, figs. 10, 11.

Pseudobolivina munda Krasheninnikov, Hemleben and Troester, 1984, p. 521, pl. 4 , fig. 3 .

Pseudobolivina munda Krasheninnikov, Moullade et al., 1988, p. 366, pl. 9, figs. 9, 10.

Pseudobolivina cf. munda Krasheninnikov, Kuhnt, 1990, pl. 6, figs. 1-2.

Recurvoides sp. 1

(Pl. 3, Figs. 9, 10)

Remarks. The small brownish forms have a chamber arrangement resembling Recurvoides deflexiformis Noth. The specimens are thin-walled with a smooth surface, similar to Haplophragmoides multicamerus.

\section{Rhizammina-Dendrophrya excelsa group}

$$
\text { (Pl. 1, Figs. 1-2) }
$$

p.p. Rhizammina indivisa Brady, 1884, p. 277, pl. 29, figs. 5-7.

p.p. Dendrophrya excelsa Drzybowski, 1898, p. 272, pl. 10, figs. 1-4.

Remarks. We did not separate the strongly fragmented tubular forms in our material. According to the mode of agglutination, degree of compression, and width of the tube and curvature, at least two different morphotypes are represented within this group which may correspond to the species Rhizammina indivisa and Dendrophrya excelsa.

\section{Subreophax scalaris (Grzybowski, 1896)}

$$
\text { (PI. 2, Fig. 4) }
$$

Reophax guttifera Brady var. scalaria Grzybowski, 1896, p. 277, pl. 8, fig. 26. Reophax scalaris Grzybowski, Hemleben and Troester, 1984, p. 521, pl. 2, figs. 10-11.

Subreophax scalaria (Grzybowski), Kaminski et al., in press, p. 187, pl. 2, figs. 16-17.

Remarks. The test consists of numerous disc-shaped, partially embracing chambers that gradually increase in size. The test is bent or curved.

Trochammina sp. 1. (?) ex gr. globigeriniformis (Parker and Jones, 1865) (Pl. 4, Figs. 11-14)

ex. gr. Lituola nautiloidea globigeriniformis Parker and Jones, 1865, p. 407, pl. 15, figs. 46-47, pl. 17, figs. 96-98.

ex gr. Trochammina globigeriniformis Parker and Jones, Cushman, 1910, p. 124, text-figs. 193-194.

Trochammina ex gr. globigeriniformis Parker and Jones, Geroch, 1960, p. 134, pl. 7 , fig. 2.

Remarks. We use the name in a broad sense and assign all small brownish Trochamminas with a four- or five-chambered test, a finely agglutinated wall, and a smooth surface to this group. Preservation of our material does not allow the observation of the apertural features. Our specimens differ from the similar
T. lobulata (Krasheninnikov, 1974) in possessing fewer chambers. It is rare in the material from the western Pacific.

$$
\begin{gathered}
\text { Trochamminoides proteus (Karrer, 1866) } \\
\text { (Pl. 3, Figs. 12, 13) }
\end{gathered}
$$

Trochammina proteus Karrer, 1866, pl. 1, fig. 8.

Remarks. This species is rare in our material and occurs only in fragments. We used the name $T$. cf. proteus in our range charts for these fragments of irregular planispiral tests with more or less rounded chambers.

$$
\text { Trochamminoides septatus (Grzybowski, 1898) }
$$$$
\text { (PI. 3, Fig. 14) }
$$

Ammodiscus septatus Grzybowski, 1898, p. 283, pl. 11, fig. 1.

Remarks. This form has a planispirally coiled test. The chamber separations are indistinct and are indicated by constrictions of the test. Examination of the type material in the Grzybowski collection of the Jagiellonian University (Krakow), showed that A. septatus is a multichambered form and thus is placed in the genus Trochamminoides. The single specimen observed in our samples from the abyssal western Pacific, corresponds well to the type material.

$$
\text { Turritellella shoneana (Siddall, 1878) }
$$$$
\text { (PI. 1, Fig. 13) }
$$

Trochammina shoneana Siddall, 1878, p. 46, figs. 1, 2.

Ammodiscus shoneanus (Siddall), Brady, 1881, p. 335.

Turritellella shoneana (Siddall), Barker, 1960, p. 78, pl. 38, figs. 17-19.

Remarks. This species has a tubular test with characteristic spiral coiling.

\section{REFERENCES}

Geroch, S., and Nowak, W., 1984. Proposal of zonation for the late Tithonianlate Eocene, based upon arenaceous foraminifera from the Outer Carpathians, Poland. In Oertli, H. J., Benthos '83: 2nd. Int. Symp. Benth. Foraminifera, Pau (April, 1983), 225-239.

Gooday, A. J., 1990. Recent deep sea agglutinated foraminifera: a brief review. In Hemleben, C., Kaminski, M. A., Kuhnt, W., and Scott, D. B. (Eds.), Paleoecology, Biostratigraphy, Paleoceanography and Taxonomy of Agglutinated Foraminifera. NATO ASI Series C: Math. Phys. Sci., 327:271-304.

Heezen, B. C., MacGregor, I. D., et al., 1973. Init. Repts. DSDP, 20: Washington (U.S. Govt. Printing Office).

Hemleben, C., and Troester, J., 1984. Campanian-Maestrichtian deep-water foraminifers from Hole 543A, Deep Sea Drilling Project. In Biju-Duval, B., Moore, J. C., et al., Init. Repts. DSDP, 78A: Washington (U.S. Govt. Printing Office), 509-532.

Jones, R. W., and Charnock, M. A., 1985. Morphogroups of agglutinating Foraminifera: their life position and feeding habitats and potential applicability in (paleo)ecological studies. Rev. Paleobiol., 4:311-320.

Krasheninnikov, V., 1973. Cretaceous benthonic foraminifera, Leg 20, Deep Sea Drilling Project. In Heezen, B. C., MacGregor, I. D., et al., Init. Repts DSDP, 20: Washington (U.S. Govt. Printing Office), 205-219.

, 1974. Upper Cretaceous benthonic agglutinated foraminifera, Leg 127 DSDP. In Veevers, J. J., Heirtzler, J. R., et al., Init. Repts. DSDP, 27 : Washington (U.S. Govt. Printing Office), 631-661.

Kuhnt, W., 1990. Agglutinated foraminifera of Western Mediterranean Upper Cretaceous pelagic limestone (Umbrian Apennines, Italy, and Betic Cordillera, Southern Spain). Micropaleontology, 36:297-330.

Kuhnt, W., Geroch, S., Kaminski, M. A., Moullade, M., and Neagu, T., in press. Upper Cretaceous abyssal claystones in the North Atlantic and the Western Tethys - the current status of biostratigraphic correlation using agglutinated foraminifers and paleoceanographic events. Cretaceous Res.

Kuhnt, W., Kaminski, M. A., and Moullade, M., 1989. Late Cretaceous deep-water agglutinated foraminiferal assemblages from the North Atlantic and its marginal seas. Geol. Rundsch., 78:1121-1140.

Kuhnt, W., and Moullade, M., 1991. Quantitative analysis of Upper Cretaceous abyssal agglutinated foraminiferal distribution in the North Atlantic-paleoceanographic implications. Rev. Micropaleontol., 34:313-349.

Loeblich, A. R., and Tappan, H., 1988. Foraminiferal Genera and their Classification: New York (Van Nostrand Reinhold). 
Moullade, M., Kuhnt, W., and Thurow, J., 1988. Agglutinated benthic foraminifers from Upper Cretaceous variegated clays of the North Atlantic Ocean (DSDP Leg 93 and ODP Leg 103). In Boillot, G., Winterer, E. L., et al., Proc. ODP, Sci. Results, 103: College Station, TX (Ocean Drilling Program), 349-377.

Neagu, T., 1990. Gerochammina N.G., and related genera from the Upper Cretaceous Flysch-Type benthic foraminiferal fauna, Eastern Carpathians-Rumania. In Hemleben, C., Kaminski, M. A., Kuhnt, W., and Scott, D. B. (Eds.), Paleoecology, Biostratigraphy, Paleoceanography and Taxonomy of Agglutinated Foraminifera. NATO ASI Ser. C: Math. Phys. Sci., 327:245-266.

Shipboard Scientific Party, 1990a. Site 800. In Lancelot, Y., Larson, R. L., et al., Proc. ODP, Init. Repts., 129: College Station, TX (Ocean Drilling Program), 33-89.

, 1990b. Site 801. In Lancelot, Y., Larson, R. L., et al., Proc. ODP, Init. Repts., 129: College Station, TX (Ocean Drilling Program), 90-170.

Date of initial receipt: 30 May 1991

Date of acceptance: 17 March 1992

Ms 129B-148

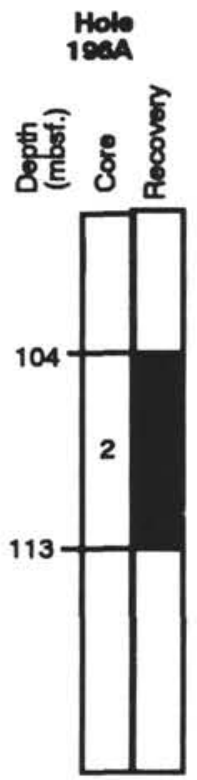

(specimens per gram sediment)

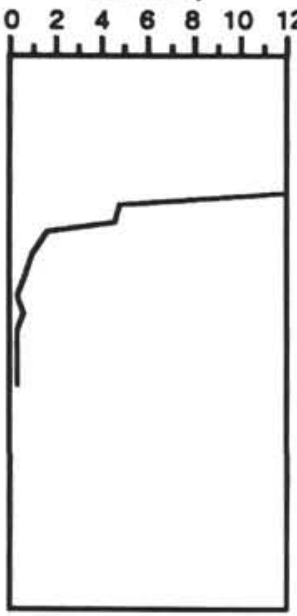

Density (number of species)
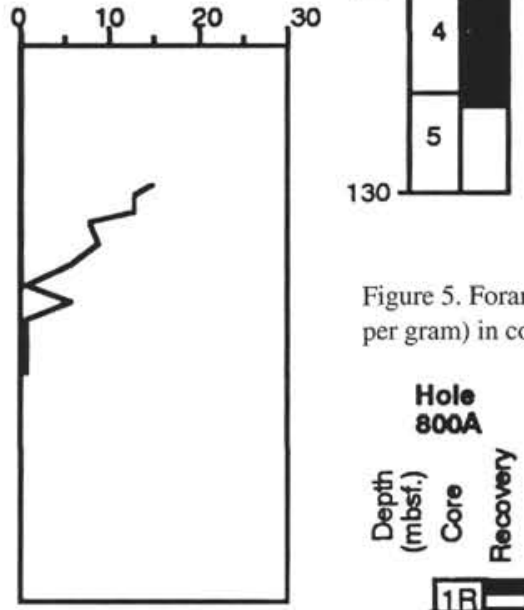

Diversity
Figure 4. Foraminiferal diversity (number of species) and density (specimens per gram) in cores from Hole 196A.

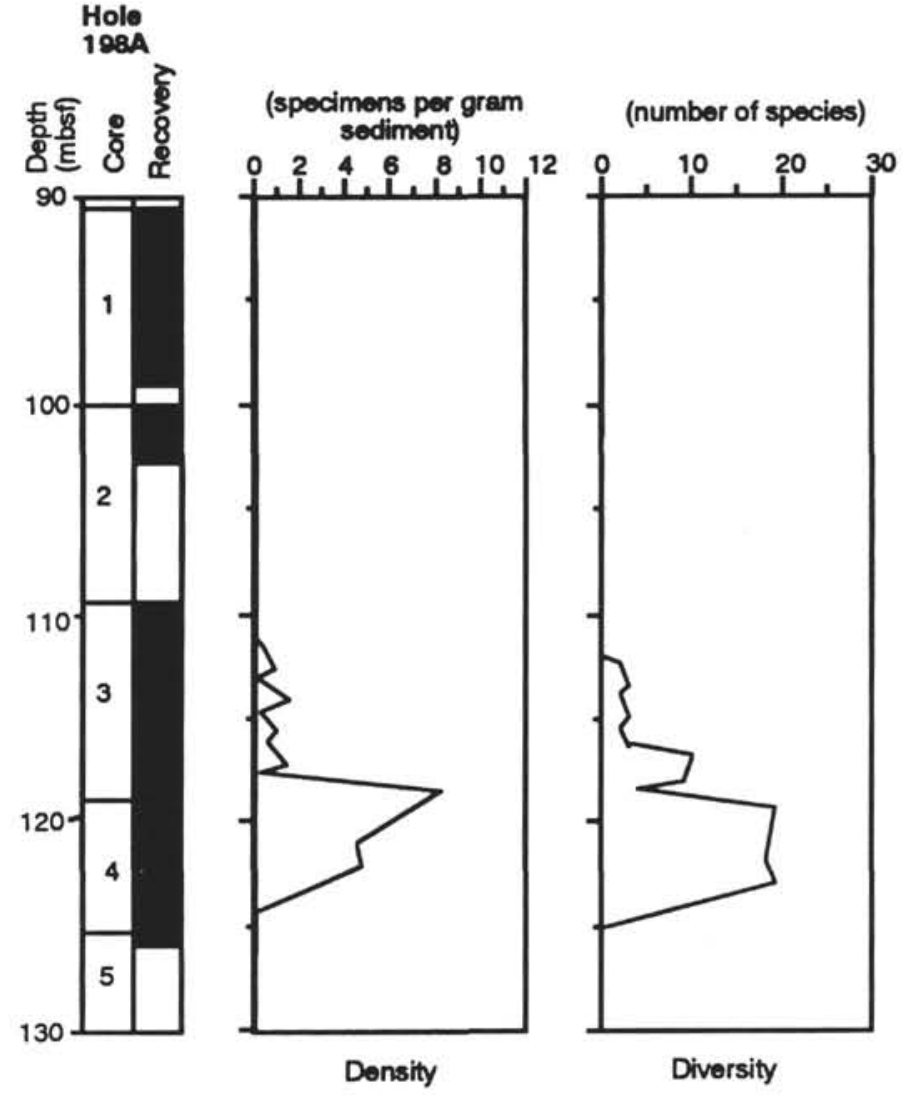

Figure 5. Foraminiferal diversity (number of species) and density (specimens per gram) in cores from Hole 198A.

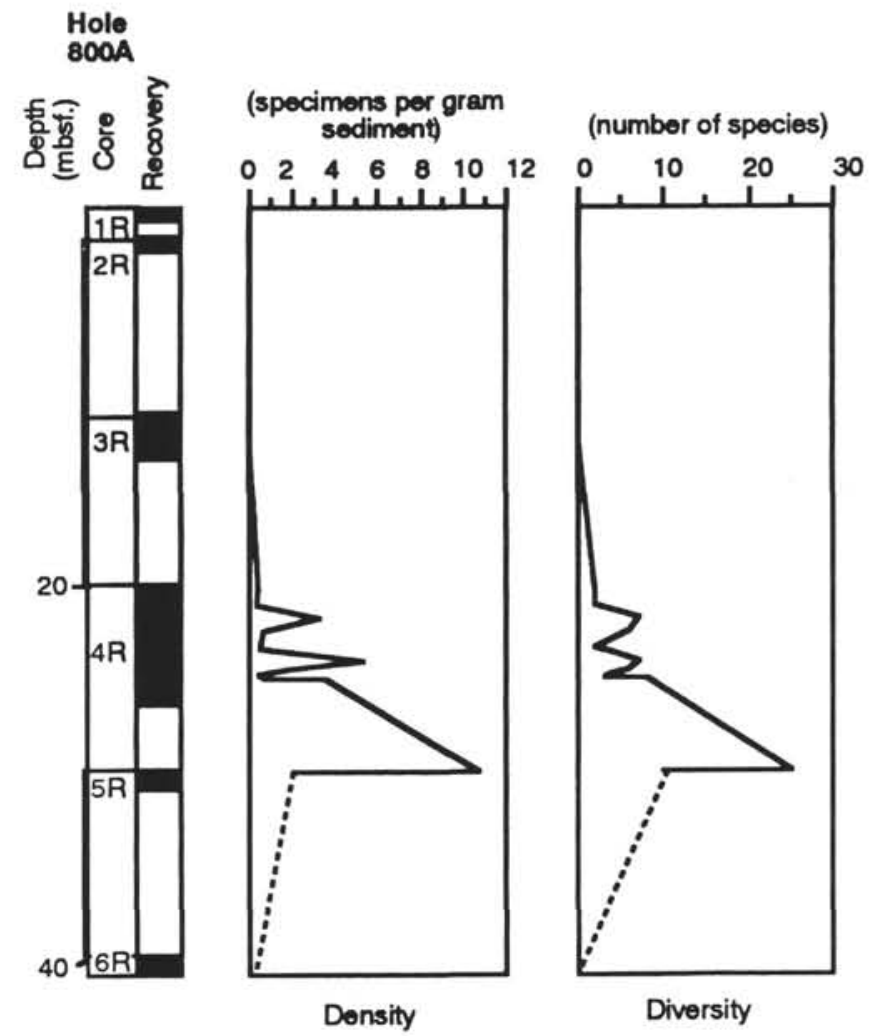

Figure 6. Foraminiferal diversity (number of species) and density (specimens per gram) in cores from Hole 800A. 


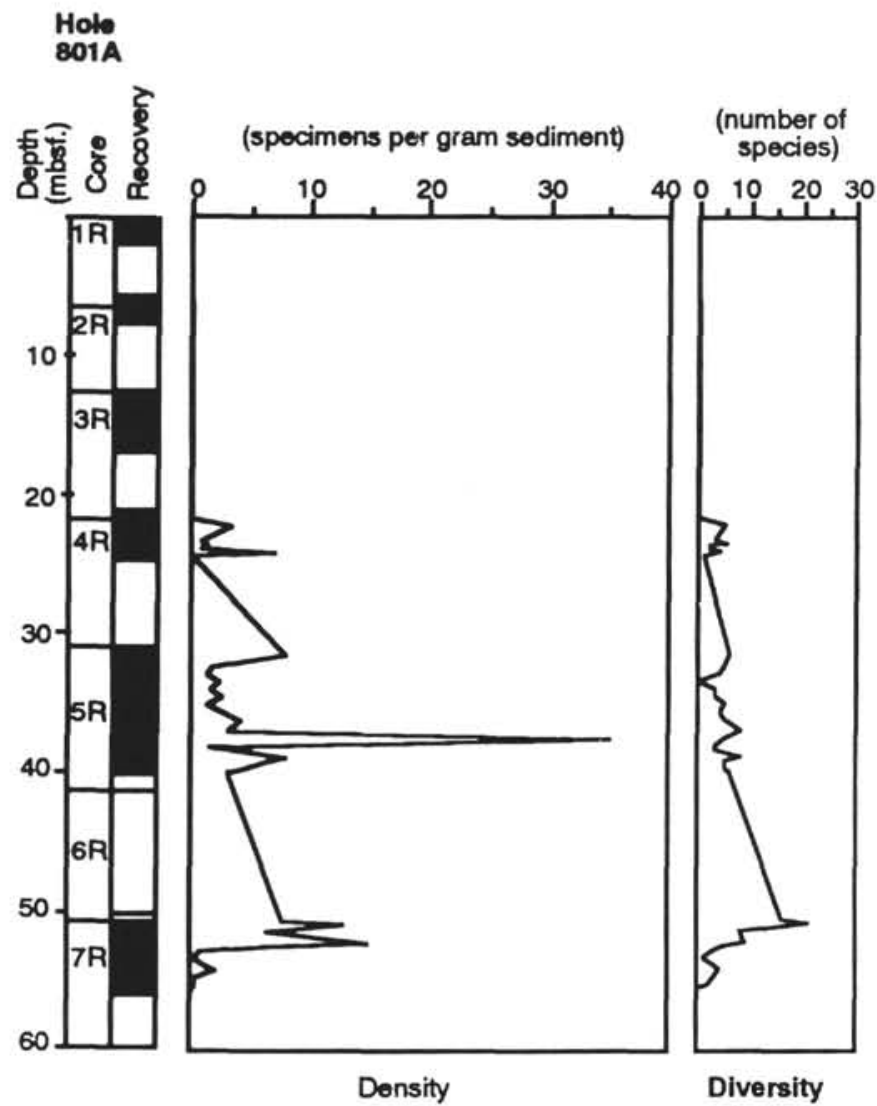

Figure 7. Foraminiferal diversity (number of species) and density (specimens per gram) in cores from Hole 801A.

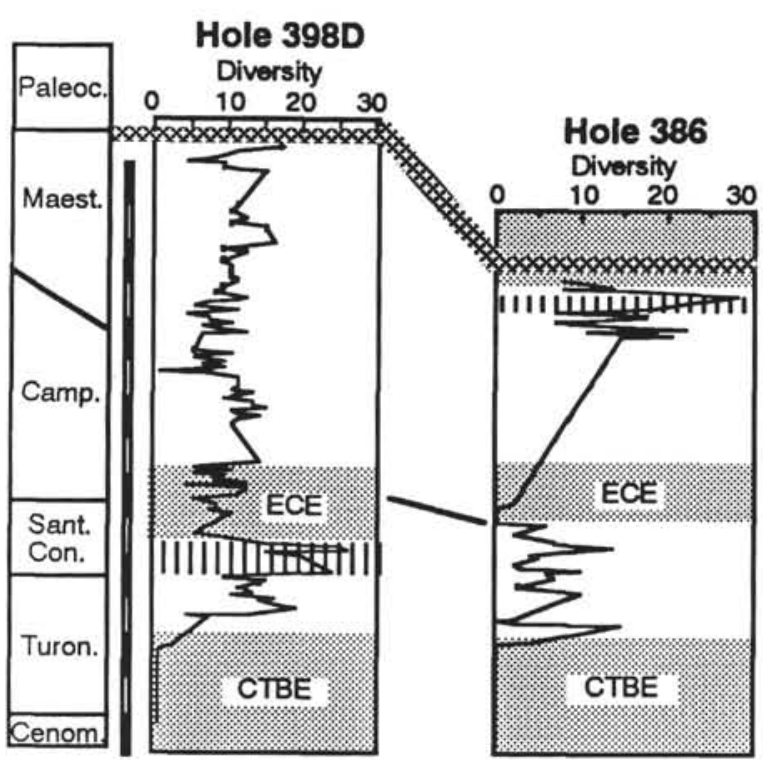

Low-diversity agglutinated foraminiferal assemblages and/or biosiliceous sedimentation IIII Peaks in abyssal agglutinated foraminiferal diversity, generally combined with high numbers of Haplophragmoides

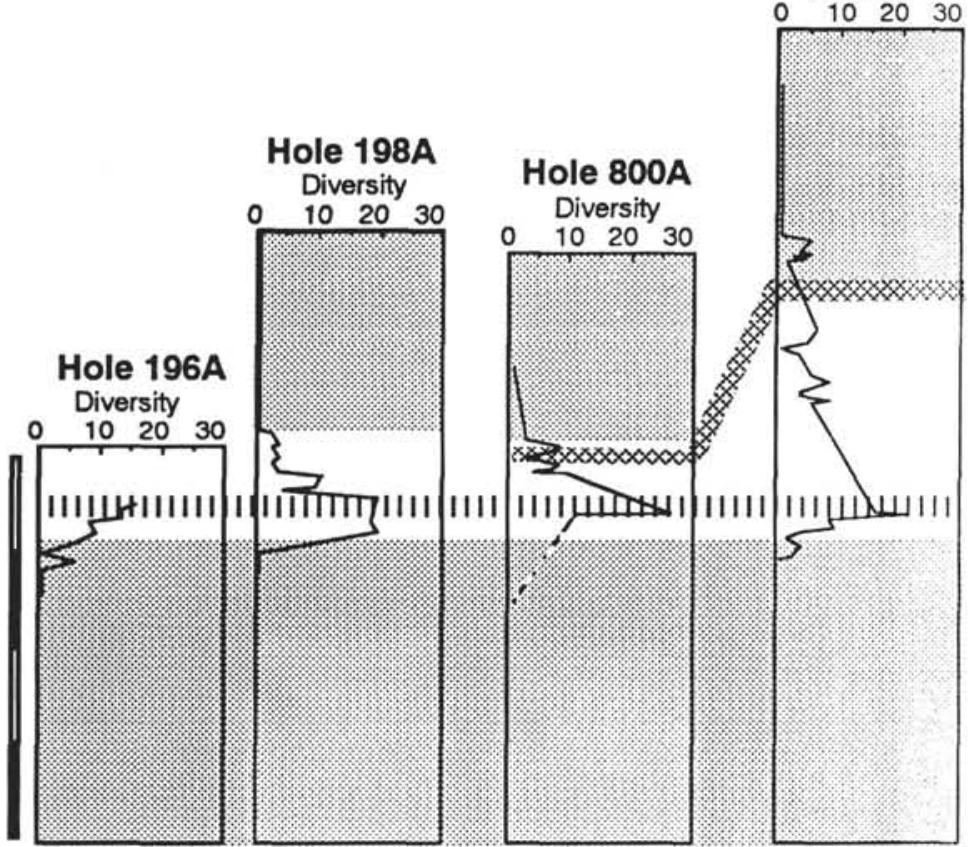

$x \times X X X X$ Approximate position of the Cretaceous/Paleocene boundary CTBE Cenomanian/Turonian boundary biosiliceous event ECE Early Campanian biosiliceous event

Figure 8. Comparison of the quantitative distribution of deep-water agglutinated foraminifers in the Upper Cretaceous of the western Pacific (Sites 196, 198, 800, and 801) and the North Atlantic (Sites 386 and 398). 


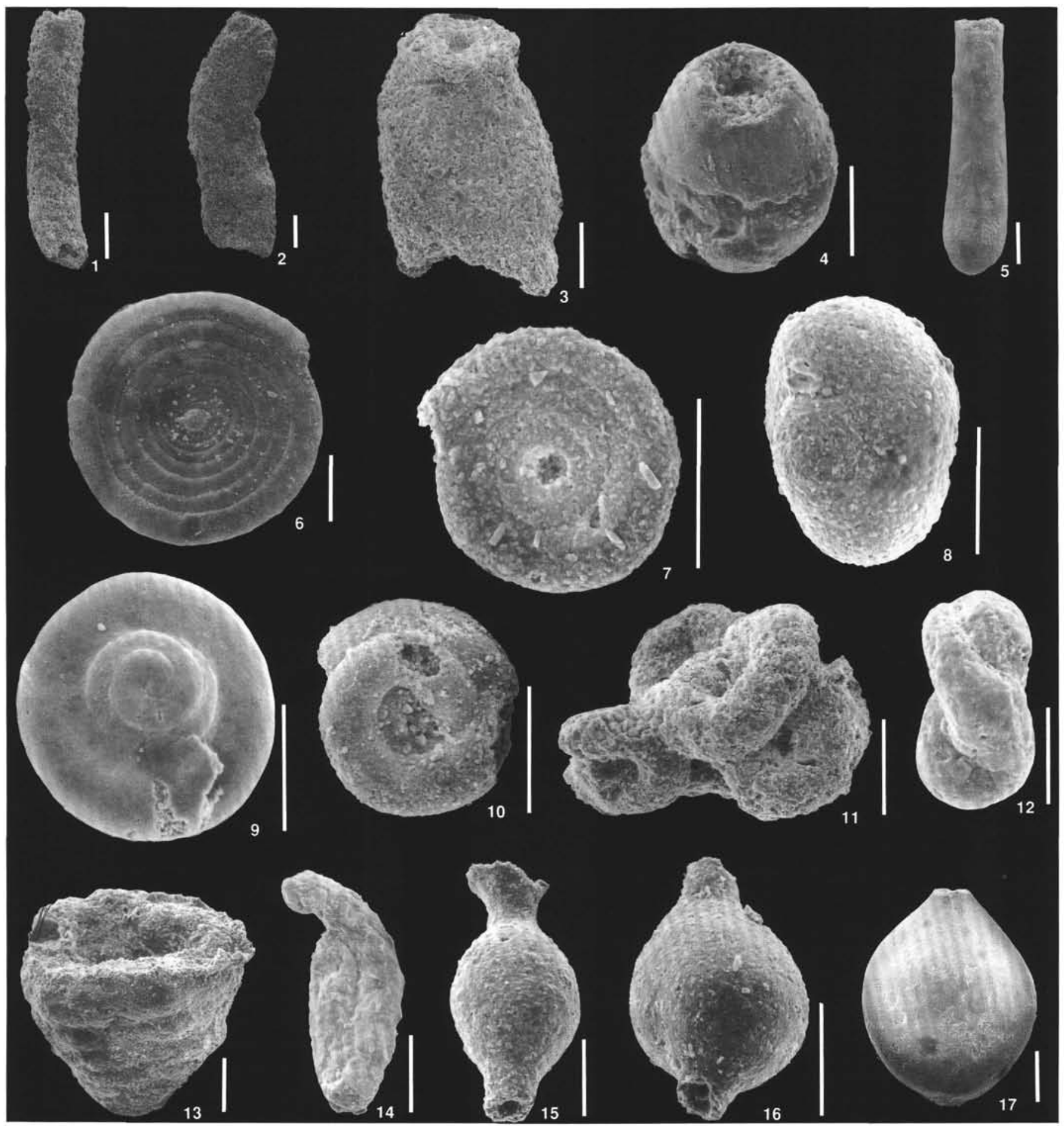

Plate 1. Scale bars $=100 \mu \mathrm{m}$. 1. Rhizammina sp., Sample 129-801A-5R-CC. 2. Dendrophrya sp., Sample 129-801A-5R-CC. 3. Aschemocella, sp., Sample 129-800A-4R-4, 5-10 cm. 4. Hyperammina dilatata, Sample 129-801A-5R-CC. 5. Hyperammina elongata, Sample 129-801A-7R-1, 124-129 $\mathrm{cm}$. 6. Ammodiscus cretaceus, Sample 129-800A-5R-CC. 7. Ammodiscus tenuissimus, Sample 20-196-2-1, 143-145 cm. 8. Buzasina pacifica, Sample 129-800A-5R-1, 15-20 cm. 9. Glomospira charoides, Sample 129-801A-5R-I, 15-20 cm. 10. Glomospira gordialis, Sample 129-801 A-7R-1, 4-9 cm. 11. Glomospira irregularis, Sample 129-800A-5R-1, 15-20 cm. 12. Glomospira serpens, Sample 129-801A-5R-1, $83-87 \mathrm{~cm}$. 13. Turritellella shoneana, Sample 129-801 A-5R-1, 117-120 cm. 14. Lituotuba lituiformis, Sample 129-801A-4R-2, 32-34 cm. 15, 16. Hormosina crassa, Sample 129-800A-5R-1, $15-20 \mathrm{~cm}$. 17. Hormosina ovulum gigantea, Sample 129-801A-4R-1, 62-67 cm. 


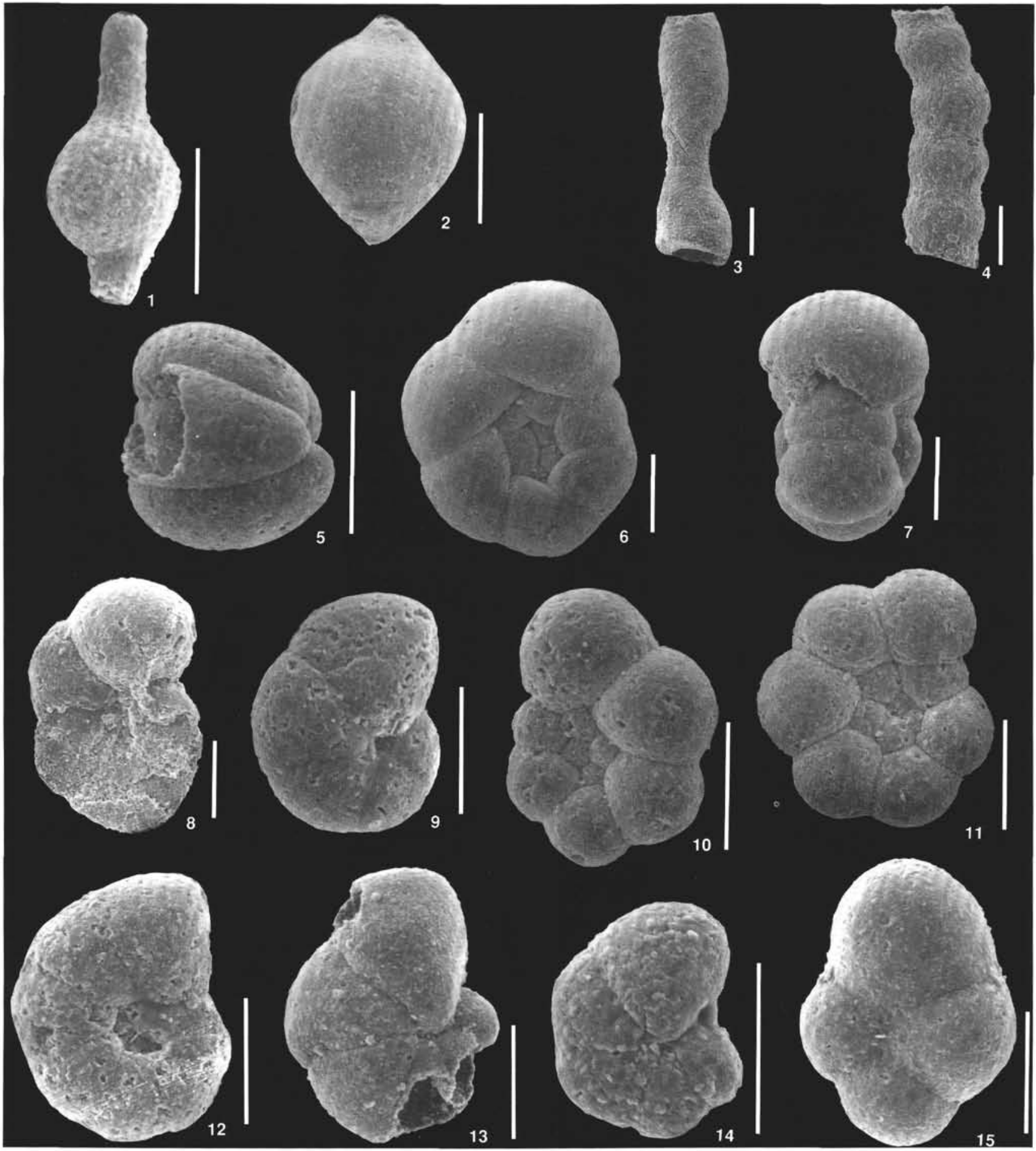

Plate 2. Scale bars $=100 \mu \mathrm{m}$. 1. Hormosina ovuloides, Sample 129-800A-5R-CC. 2. Hormosina ovulum ovulum, Sample 129-800A-5R-CC. 3. Kalamopsis grzybowskii, Sample 129-801A-6R-CC. 4. Subreophax scalaris, Sample 129-800A-5R-1, 15-20 cm. 5. Adercotryma sp. Sample 20-196A-2-1, 143-145 cm. 6, 7. Haplophragmoides biumbilicalis, Sample 129-800A-5R-1, 15-20 cm. 8. Haplophragmoides cf. concavus, Sample 129-801A-7R, 4-9 cm. 9. Haplophragmoides decussatus, Sample 129-800A-4R, 96-98 cm. 10, 11. Haplophragmoides fraudulentus, Sample 129-800A-5R-1, 15-20 cm. 12. Haplophragmoides ex gr. herbichi, Sample 20-198A-4-2, 20-24 cm. 13, 14. Haplophragmoides incredibilis, Sample 20-198A-4-2, 20-24 cm. 15. Haplophragmoides krasheninnikov, Sample 20-196A-2-1, 65-68 cm. 


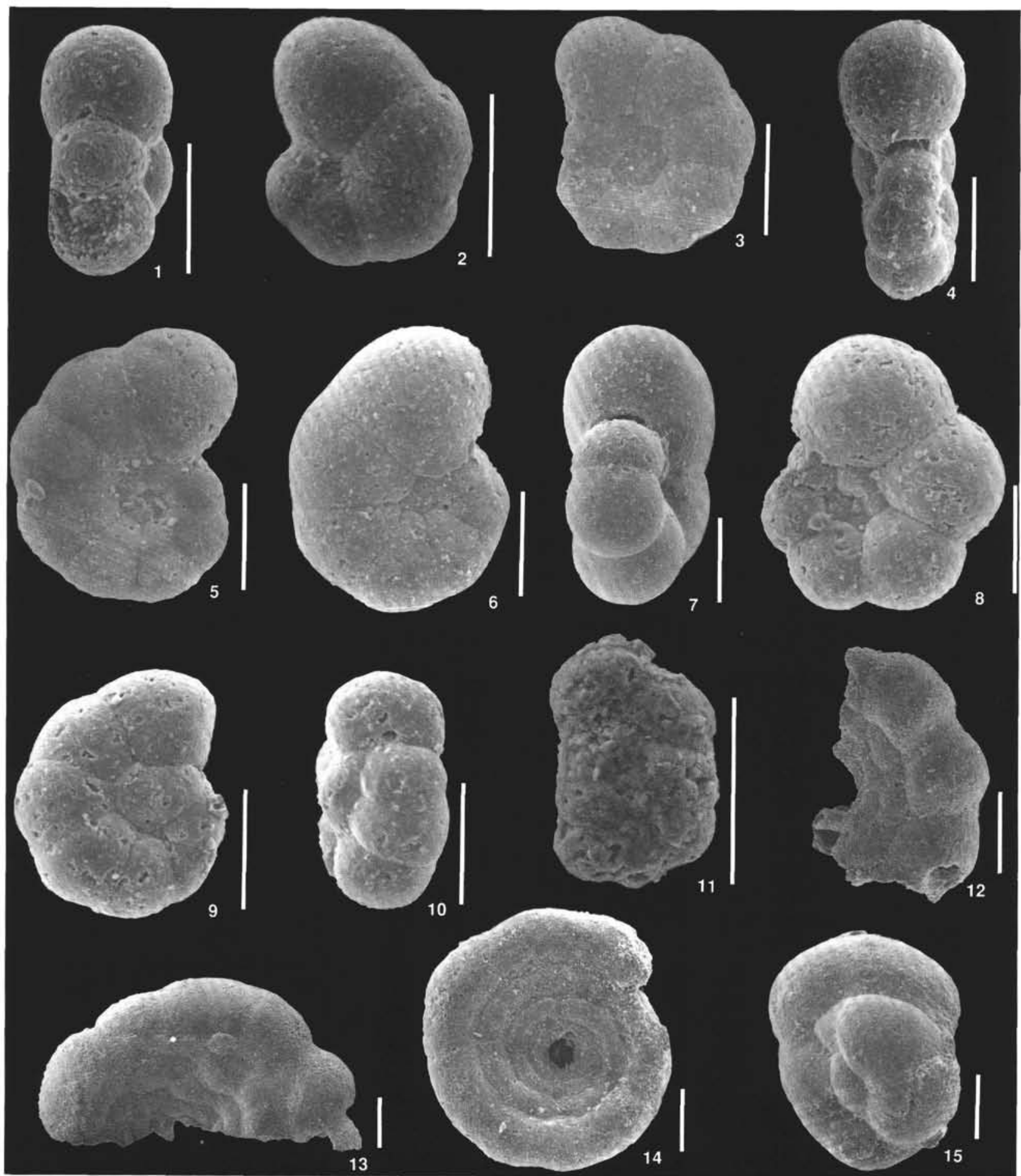

Plate 3. Scale bars $=100 \mu \mathrm{m}$. 1. Haplophragmoides krasheninnikovi, Sample 20-196A-2-1,65-68 cm. 2. Haplophragmoides molestus, Sample 20-196A-2-1, 1-4 cm. 3, 4, 5. Haplophragmoides multicamerus, Sample 129-801A-6R-CC (3), Sample 129-800A-5R-CC (4, 5). 6, 7, 8. Haplophragmoides ex gr. perexplicatus-constrictus, Sample 129-800A-5R-1, 15-20 cm. 9, 10. Recurvoides sp., Sample 20-198A-3-6, 13-18 cm. 11. Bolivinopsis parvissimus, Sample 129-800A-5-1, 83-87 cm. 12, 13. Trochamminoides proteus, Sample 129-800A-5R-1, 15-20 cm. 14. Trochamminoides septatus, Sample 129-801A-7R-1, 4-9 $\mathrm{cm}$. 15. Paratrochamminoides corpulentus, Sample 129-801A-7R-1, 4-9 cm. 


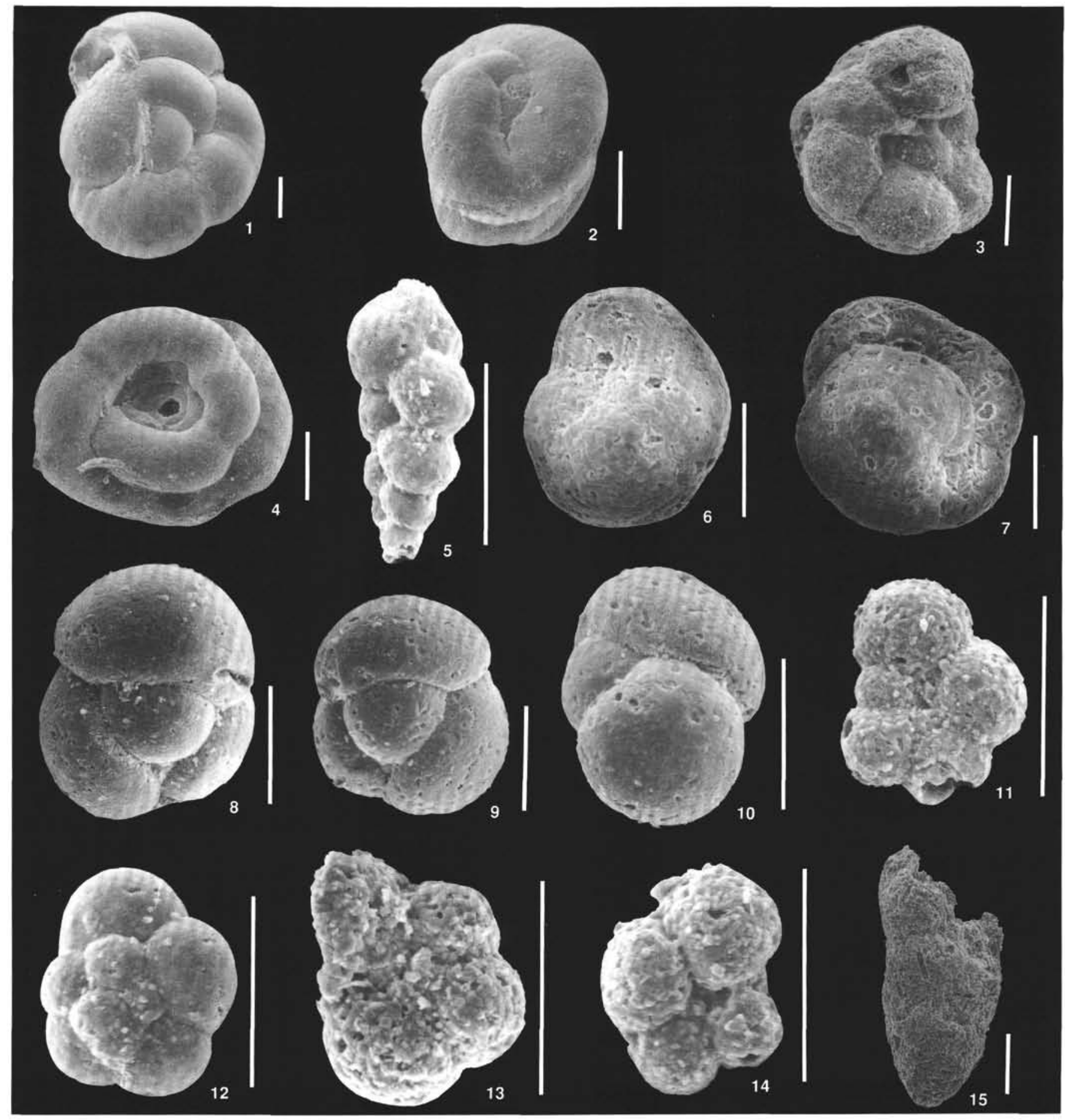

Plate 4. Scale bars $=100 \mu \mathrm{m}$. 1. Paratrochamminoides corpulentus, Sample 20-198A-3-6, 113-118 cm. 2. Paratrochamminoides dubius, Sample 20-198A3-6, 113-118 cm. 3. Paratrochamminoides intricatus, Sample 129-801A-7R-1, 4-9 cm. 4. Paratrochamminoides olszewskii, Sample 20-196A-2-1, 143-145 $\mathrm{cm}$. 5. Pseudobolivina munda, Sample 129-800A-4R-4, 27-29 cm. 6. Plectorecurvoides parvus, Sample 20-196A-2-1, 143-145 cm. 7. Plectorecurvoides rotundus, Sample 20-196A-2-1, 143-145 cm. 8,9, 10. Praecystammina globigerinaeformis, Sample 129-801A-7R-1, 124-129 cm. 11, 12, 13, 14. Trochammina sp. 1, Sample 129-801 A-6R-CC (11, 12), Sample 129-801A-4R-2, 55-57 cm (13, 14). 15. Karrerulina sp., Sample 129-800A-5R-1, 15-20 cm. 